\title{
Liquidity and the Evolution of Price Discovery on Floor versus Screen- Based Trading Systems: An Analysis of the Foreign Exchange Futures Markets
}

\author{
By \\ Aysegul Ates and George H. K. Wang*
}

This Version, May, 2005

Keywords: Microstructure, Foreign Exchange Futures Markets, Floor versus Screen Trading.

JEL Classification: G10

\footnotetext{
* The authors would like to thank Paul Dawson for his helpful comments. Aysegul Ates is an Assistant Professor of Economics, Department of Economics, Akdeniz University, Turkey, and George H. K. Wang is the Deputy Chief Economist, Office of Chief Economist, Commodity Futures Trading Commission and Adjunct Professor of Finance, School of Management, George Mason University, Fairfax, Virginia. The views expressed in this paper are those of the authors and do not necessarily reflect the views of the Commodity Futures Trading Commission or its staff.
} 


\title{
Liquidity and Evolution of Price Discovery on Floor versus Screen- Based Trading Systems: An Analysis of Foreign Exchange Futures Markets
}

\begin{abstract}
This paper examines the relative liquidity and rate of price discovery on floorbased versus screen-based trading systems in the Japanese Yen, British Pound, and Euro foreign exchange futures markets traded on the Chicago Mercantile Exchange (CME). Intra-day data from January 2, 2003 through March 5, 2004 are used in our analysis. We find that liquidity, measured by bid-ask spreads, is tighter in the automated trading system before and after controlling for such variables as price volatility and trading volume. For trading that occurred during the earlier part of the sample period, i.e., calendar year 2003, floor-based trading typically contributed more to price discovery in the Japanese Yen and British Pound markets. However, in the latter part of the sample period, i.e., calendar year 2004, screen trading took the dominant role and contributed more to price discovery in these same markets. Automated trading dominated price discovery in the Euro foreign exchange futures market during the entire 2003-2004 sample period. The results of our regression analysis support the hypothesis that relative liquidity and operational efficiency jointly influence the contribution shares in the price discovery process.
\end{abstract}




\section{Liquidity and the Evolution of Price Discovery on Floor versus Screen- Based Trading Systems: An Analysis of the Foreign Exchange Futures Markets}

\section{Introduction}

As a result of developments in information technology and globalization, electronic trading systems have been increasingly adopted by equity and futures exchanges. In the U.S., two major futures exchanges, the Chicago Board of Trade (CBOT) and the Chicago Mercantile Exchange (CME), permit market participants to

choose between floor and screen-based trading systems for most futures contracts during regular trading hours. The electronic trading system is also used by CBOT and CME as a supplementary trading mechanism during off-hours trading. However, the CME and CBOT still execute a considerable portion of their transactions (in dollar value) through the floor-based trading system.

Several studies have compared CME's electronic trading system (GLOBEX) and floor trading in terms of informational efficiency (Hasbrouck 2003, Kurov and Lasser 2002, and Ates and Wang 2003). These studies focus on floor-traded equity index futures and electronically-traded E-mini equity index futures. Although these contracts are based on the same index, they have different contract sizes, and their customer base might be different due to this feature. ${ }^{1}$ More recently, the CME introduced side-by-side trading in currency futures. Identical contracts began trading simultaneously on GLOBEX and on the floor on April 2, 2001. Our study focuses on the impact of electronic trading on price discovery and liquidity in identical currency futures contracts.

Open-outcry trading (floor-based trading) is comparable to a continuous dealer market and electronic trading is comparable to a continuous order-driven market. 
Supporters of electronic trading argue that the electronic trading system possesses the following merits over the open-outcry trading system: (1) faster speed and accuracy in processing transactions; (2) lower operating costs; and (3) open access to the limit order book and anonymity of trader identification. Based on these advantages, the advocates of automated trading believe that the electronic trading system would enhance market liquidity and result in a larger contribution to the price discovery process. On the other hand, the critics of electronic trading systems claim that electronic trading eliminates strategy-based informational advantages that market makers possess in the open-outcry trading pit. Furthermore, the liquidity suppliers face larger adverse information costs when submitting their orders to the limit order book because of the possibility of trading with anonymous counterparts. Thus, it is believed that market makers increase their effective bid-ask spreads in order to compensate for their potential losses to informed traders. As a result, trading costs may rise. This increase in trading costs reduces the liquidity of the contract market which, in turn, will cause the electronic trading system to make less of a contribution to the price discovery process.

The main objectives of this paper are: (1) to empirically compare the relative liquidity of the same foreign exchange (FX) futures contracts that are traded side-by-side in both trading systems (electronic vs. floor), during regular trading hours; (2) to examine the price discovery role played by the electronic trading market versus the floor trading market during high versus low volatility periods; and (3) to test the hypothesis that operational efficiency and relative liquidity jointly determine the contribution of each asset traded under different trading systems to price discovery. 
Our paper is closely related to a previous study by Coppejans and Domowitz (1999), who examined the bid-ask spread of automated trading during "off-exchange hours" and floor trading in regular hours in selected currency futures markets, with intraday data from July 1, 1994 to September 1, 1994. However, our paper improves upon Coppejans and Domowitz's (1999) in two ways. First, we examine the bid-ask spreads between electronic trading versus floor trading in currency futures markets using updated and longer intraday data for regular trading hours. Second, our paper extends Coppejans and Domowitz's analysis during the same (regular) trading hours.

Intraday data sets of the Japanese Yen, British Pound, and Euro FX futures contracts are used in this study. Our data set has advantages over the data set used by previous studies. A comparison of open-outcry and electronic trading using CME's FX futures data gives us a controlled experiment of two trading system characteristics, since the FX futures contracts traded in both trading mechanisms are identical. (See Table A.1 in the appendix for contract definitions). This eliminates the weaknesses in previous studies which suffered from "contract specification bias" or "home country bias." The price reversal method is used to estimate the bid-ask spread, and information shares (Hasbrouck 1995) and common long-memory factor weights (Gonzalo and Granger 1995) are employed to measure the contribution by each trading mechanism in these FX futures markets to the price discovery process.

Several interesting empirical results have been obtained, based on intraday data from January 2, 2003 through March 5, 2004. We have found that bid-ask spreads were lower for automated trading after controlling for such variables as price volatility and trading volume in a regression framework in the Japanese Yen, British Pound, and Euro 
futures markets. During the calendar year 2003 sample period, floor-based trading typically contributed more to price discovery in the Japanese Yen and British Pound futures markets. However, in calendar year 2004, the situation reversed, and screen trading typically contributed more to price discovery in the Japanese Yen and British Pound futures markets. During the whole sample period, electronic trading was the dominant contributor to price discovery in the Euro futures market. A regression analysis reveals that alternative measures of liquidity variables between markets are the determinants of dynamics of information shares over time. Our results are consistent with the hypothesis that relative liquidity determines the rate of the price discovery process.

The rest of the paper proceeds as follows: Section II presents a literature review of liquidity and the information transmission relationship in futures markets under alternative trading systems. In Section III, we formulate our hypotheses on relative liquidity and the information transmission relationship between screen-trading versus floor trading of FX futures. Section IV discusses the contract specifications and the sources of data. Section V reports liquidity measures. In Section VI, the results of the measures of contributions to price discovery are reported. Results of the regression analysis on the relationships between liquidity and information shares are reported in Section VII. Finally, Section VIII contains a summary and conclusions.

\section{Literature Review}

Empirical literature on relative liquidity and price discovery under alternative trading systems (i.e. electronic vs. open-outcry) in futures markets is accumulating. In general, the futures literature related to our study can be divided into two groups. 
The first line of research examines the liquidity and/or price discovery under alternative trading systems in non-US futures markets. Most of these papers focus on German Bund futures trading on the DTB (electronic trading system) and on LIFFE (floor-based trading system). Kofman and Moser (1997), Pirrong (1996), Frino, McInish and Toner (1998) are in this group. Pirrong (1996) finds that effective bid-ask spreads in electronically-traded German Bund futures on the DTB are no greater than effective bidask spreads in floor-traded German bund futures on LIFFE. The papers that study price discovery in these two markets include Shyy and Lee (1995), Kofman and Moser (1997), Martens (1998) and Franke and Hess (2000). Shyy and Lee (1995) and Kofman and Moser (1997) find that price changes on the DTB lead price changes on LIFFE. However, both studies employ a very short time period. ${ }^{2}$ Martens (1998) and Franke and Hess (2000) provide empirical evidence that LIFFE German bund futures made a larger contribution to price discovery during periods of high volatility and DTB German bund futures made a larger contribution to price discovery during periods of low volatility. However, these studies suffer from home country bias.

Gilbert and Rijken (2003) examine the bid-ask spread of the FTSE 100 before and after the LIFFE moved from a floor trading to an electronic trading system. They find that the bid-ask spread of the FTSE 100 is smaller after the move from a floor trading to an electronic trading system. Aitken et al. (2004) study the impact of electronic trading on bid-ask spreads and find that the bid-ask spreads of futures contracts are lower in Hong Kong, London, and Sydney futures exchanges following their switch to an electronic trading system. 
The second line of research focuses on the effects of automation in price discovery and/or liquidity in US futures markets. Coppejans and Domowitz (1999) address the characteristics of automated markets on the CME. They study automated trading during "off exchange hours" and floor trading during regular trading hours in the S\&P 500, Deutschemark, Yen, and Swiss Frank futures markets from July 1, 1994 through September 1, 1994. They find that bid-ask spreads in the S\&P 500 futures markets are very close to each other in both trading mechanisms; however, bid-ask spreads are much higher in electronic trading in currency futures markets. Their findings also show that the adverse selection component is larger in electronic trading for all currencies except the Deutschemark (DM).

The remaining papers focus on regular index futures and E-mini index futures traded on the CME under alternative trading mechanisms. Hasbrouck (2003) examines the price discovery process among equity index futures, E-mini index futures and Exchange Traded Funds (ETFs) in the S\&P 500 and Nasdaq 100 index derivative markets using intraday data from March 1, 2000 to May 31, 2000. He finds that E-mini equity index futures play a dominant role in the price discovery process in these markets. Using intraday data from May 7, 2001 to September 7, 2001, Kurov and Lasser (2002), examine the price discovery process in the S\&P 500 and Nasdaq 100 index futures markets. They find that the price discovery process is in fact initiated in electronically traded E-mini index futures markets and is driven by trades initiated by exchange locals who can also access E-mini index futures markets. Ates and Wang (2003) examine the price discovery process between equity index futures and E-mini index futures in the S\&P 500 and Nasdaq 100 index futures using intraday data from 1998 to 2001. Their 
results show that both E-mini and regular index futures contribute to the information transmission process, but since 1999, E-mini futures have become dominant in price discovery. They also demonstrate that the information share is positively related to the market share of E-mini futures trading.

In summary, previous empirical studies in this area suffer from either one or both of the following deficiencies: (1) they do not control for the differences in contract definitions or home country biases; and (2) they use either a very liquid time period or an initial introduction time period for evaluating electronic versus open-outcry trading mechanisms, and the validity of their empirical results rests on the limited time period employed. Our paper overcomes the various deficiencies of these earlier studies.

\section{Hypotheses on Liquidity and Price Discovery under Alternative Trading}

\section{Systems}

In this section, we discuss the differences in operational efficiency and informational efficiency between electronic and open-outcry systems. These differences in attributes would influence a trader's choice of alternative trading systems. This, in turn, would have implications for relative liquidity and the rate of price discovery in these two trading systems.

\subsection{Differences in Operational Efficiency}

The proponents of the electronic matching system claim that automated trading is operationally more efficient than floor trading. Their main arguments can be summarized as follows. First, automated trading provides convenient and rapid delivery of customers' orders for execution and immediate customer notification of an execution. ${ }^{3}$ By contrast, in floor trading, customers' orders are delivered by runners to the brokers in the pit. 
(However, the open-outcry system has recently introduced an electronic order routing and reporting system to accelerate this process; this will reduce the relative advantage of a speedy execution of orders by automated trading.) Second, electronic trading allows market participants to monitor the status of their orders throughout the execution process and reduces the possibility of trade abuses (i.e. dual trading issue). Third, the floor trading system always faces "out trade" (or error trade) problems. Greater out trades equal greater potential loss for the traders and greater risk due to delays in resolving errors that may arise. By contrast, the electronic matching system minimizes any out trades and facilitates the clearing of trades by member firms. Fourth, fairness of the First In First Out (FIFO) systems results in no differentiation between customers. Fifth, electronic trading allows traders to reach many markets at the same time and offers a greater distribution potential due to the unlimited number of terminals, whereas the number of locals in the floor trading system is limited by the capacity of the trading pits. Finally, it is easier and less costly to monitor the credit worthiness of traders in an electronic trading platform than it is in the open-outcry system during periods of high volatility. ${ }^{4}$

In summary, the electronic trading system seems to have advantages in operational efficiency. These advantages imply that electronic trading would have a relatively lower order processing cost component in its effective bid-ask spread than would electronic trading.

\subsection{Differences in Informational Efficiency}

The differences between floor trading and electronic trading systems in the accessibility of timely market information to traders are summarized below. 
First, in pit trading, local traders know who is bidding, who is offering, and who is trading with whom. Furthermore, a local trader can observe brokers' activity such as outside orders driving the markets or trading to balance their positions. In contrast, electronic matching systems (e.g. GLOBEX) do not disclose who is bidding or offering; thus, one does not know with whom one is trading. In general, floor trading offers locals more transaction details than electronic trading systems.

Second, in the pits, traders can select their counter party. Because a broker can choose whom to trade with, locals can observe the broker's choices and avoid trading with informed traders. The opportunity to observe order flow and other traders' behavior (endogenous information) on the floor is extremely valuable in the information intense (high volatility) trading period. ${ }^{5}$ The electronic matching systems do not allow traders to select their counter party. Furthermore, quotes posted by locals on the screen provide a free option to informed traders.

Third, locals operating on an electronic trading system can have direct access to numerous news media and trading support software. Furthermore, such a system allows outside orders to arrive at the market more quickly than does a floor trading system. Locals on the trading floor only receive news from a limited sample of news displayed on the walls of the exchange floor as well as from runners.

Fourth, Franke and Hess (2000) and Martens (1998) argue that, during low volatility periods, the limit order book offers traders useful information on the depth of the market and hence, insight into the market. By way of contrast, locals in the pits can only observe the best bid and ask as it is announced and do not have access to a limit order book. The observation of other traders' behavior and transaction details is less 
informative because there are not many transactions on the floor. Thus, the open-outcry trading system provides less information on market depth in a low volatility period.

In a high volatility period, however, these authors argue that a trader in the openoutcry market can change his price quote by a simple hand signal and verbal announcement, thus canceling his previous bid or offer. By contrast, a trader in an electronic trading market experiences certain slackness in the market's ability to accept a change in old quotes as well as the submission of new quotes. Response time is further challenged during high-volatility periods due to an increase in message traffic. Based on these considerations, Franke and Hess (2000) and Martens (1998) suggest that the electronic trading systems' contribution to information shares is relatively larger in quiet periods than it is in volatile periods. ${ }^{6}$

In short, locals in the floor trading system have access to more strategic information than locals in the electronic matching system. The electronic matching system offers locals more technical informational advantages than the floor trading system. On balance, electronic trading systems do not seem to offer locals greater informational advantages over the floor trading system.

\subsection{Hypotheses}

Based on the above analysis, our hypotheses on the liquidity and price discovery relationship between electronically-traded FX futures and floor-traded FX futures are formulated as follows:

(1) The bid-ask spreads would be lower in electronically-traded FX futures if the advantage of the lower order processing cost component in electronic trading 
exceeds the disadvantage of having a relatively higher adverse selection component.

(2) Electronically traded FX futures make a dominant contribution to price discovery during periods of low price volatility, and a secondary contribution to price discovery during periods of high volatility.

(3) Liquidity (measured by differences in bid-ask spreads, market shares and ratios of trading frequency) and relative operational efficiency jointly determine the share of information contributed by alternative trading systems in the price discovery process.

In summary, our price discovery hypothesis follows the trading cost hypothesis suggested by Fleming, Ostdiek, and Whaley (1996) in explaining the relative rate of price discovery in stock futures and option markets by considering both the relative operational efficiency as well as liquidity (i.e. trading cost) in determining the rate of the price discovery relationship.

\section{Data Description}

The primary data used in this study consists of six intraday transaction price histories: Japanese Yen futures (floor-traded and screen traded), British Pound futures (floor-traded and screen traded), and Euro futures (floor-traded and screen traded). These futures are included in this study because they are among the most active FX futures contracts trading at the CME. By studying these markets, we avoid a possible bias caused by infrequent trading.

The floor-traded and electronically-traded Japanese Yen futures have identical contract specifications. The contract size is $12,500,000$ Japanese Yen and the minimum 
tick is $\$ 12.50$ per contract. Both contracts have the same expiration date and have a physical delivery settlement. There are four contract months: March, June, September, and December. The trading hours for open-outcry are from 7:20 a.m. to 2:00 p.m. (central time) and the trading hours for GLOBEX are 4:30 p.m. to 4:00 p.m. the following day, Monday through Friday. Sunday trading begins at 5:30 p.m.

The electronically-traded and floor-traded British Pound futures share almost the same contract specification as the Japanese Yen futures contract with the exception of contract size and tick size. The contact size of the British Pound futures is 62,500 British Pounds and the minimum tick is 0.0001 (i.e. $\$ 6.25$ per contract) ${ }^{7}$. Floor-traded and electronically-traded Euro futures have identical contract specifications. The contract size is 125,000 Euros and the minimum tick is $\$ 12.50$ per contract. The details of the contract specifications of these contracts are given in Table A.1 in the appendix.

Our sample period for this study extends from January 2, 2003 to March 5, 2004. The nearby contracts are used in our analysis since they are the most active contracts in terms of trading volume. To construct a continuous time series, the first deferred contract is switched into the nearby contract one week prior to the expiration of the nearby contact. Half trading days are excluded from the data set.

The intraday time and sales data and Computer Trade Reconstruction (CTR) data for these six futures contracts are obtained from the CFTC database. The daily trading volume of the six contracts during the parallel trading hours is calculated from CTR data. The price series are actual transaction prices for all trades during the day. For that reason, they are not uniformly spaced in time. To assess the degree of comovement among the prices in different markets, it is necessary to define and compare 
returns over a standardized time interval. Therefore, a 30-second data set is constructed for each price series. To generate a synchronized price series, a daily time grid is established. The grid begins at 7:20 a.m. (CST), and proceeds at thirty second intervals until 2:00 p.m. For each of the data series the grid contains the last reported price in each interval. Any interval between these initial and terminal points that does not contain a price observation for a given series is assigned the price from preceding intervals.

The 30-second price series are then used to generate a time series of returns for floor-traded FX futures and their corresponding electronically-traded counterparts during parallel trading hours. Price changes (returns) were constructed from the difference in log price relatives.

\section{Measuring Liquidity}

Liquidity is one of the most important attributes of a trading system. A financial market is a liquid market if a large transaction size can be executed with minimum time delay and minimum price change. Thus, the definition of liquidity involves three elements: time, transaction size and price impacts. The bid-ask spreads are the results of the interaction of these three elements and are commonly employed as a measure of the liquidity of the market.

The price reversals method is used to estimate the daily realized spreads with the use of intraday time and sales data. ${ }^{8}$ The bid-ask spreads are estimated as follows: (i) an empirical joint price distribution of $\Delta \mathrm{P}_{\mathrm{t}}$ and $\Delta \mathrm{P}_{\mathrm{t}-1}$ during a daily interval is created, (ii) the subset of price changes that exhibit price continuity (i.e., a positive change followed by another positive change) is discarded; (iii) the absolute value of price changes that are reversals are taken; and (iv) the mean of absolute values obtained from step (iii) is 
computed. This method is widely used in empirical studies of bid-ask spreads in futures market literature. ${ }^{9}$

Table 1 reports the estimates of bid-ask spreads for the floor-traded and screentraded Japanese Yen, British Pound, and Euro futures contracts for the period from January 2, 2003 through March 5, 2004. Figure 1 presents a time series plot of these bidask spreads. We find that the means of the bid-ask spreads of floor-traded Japanese Yen, British Pound, and Euro futures are wider than the means of the bid-ask spreads of their electronically-traded counterparts. The higher spreads in floor trading may be due to the possibility of having a larger order processing and inventory cost component. ${ }^{10}$ Our results differ from Coppejans and Domowitz (1999). They find that electronically-traded Japanese Yen futures have higher bid-ask spreads (three to four ticks) than floor-traded Japanese Yen futures during off-hours than during regular trading hours. Their results are due to the fact that electronic trading lacks liquidity during overnight trading.

To control the effects of other variables on effective bid ask spreads, we perform an analysis of the covariance model to test the equality of floor-based effective spreads versus the electronic trading effective spreads for our data. The covariance model is specified as follows:

$$
\mathrm{BAS}_{\mathrm{i}, \mathrm{t}}=\beta_{0}+\beta_{1} \mathrm{TV}_{\mathrm{i}, \mathrm{t}}+\beta_{2} \mathrm{IV}_{\mathrm{i}, \mathrm{t}}+\beta_{3} \mathrm{BAS}_{\mathrm{i}, \mathrm{t}-\mathrm{l}}+\beta_{3} \mathrm{D}_{\mathrm{GLOBEX}}+\varepsilon_{\mathrm{i}, \mathrm{t}}
$$

where

$\mathrm{i}=$ floor trading, electronic trading;

BAS $_{i, t}=$ Daily bid-ask spreads of trading system $\mathrm{i}$ on the day $\mathrm{t}$;

$\mathrm{TV}_{\mathrm{i}, \mathrm{t}}=$ Daily trading volume of trading system $\mathrm{i}$ on the day $\mathrm{t}$;

$\mathrm{IV} \mathrm{i}_{\mathrm{i}}=$ Intraday price volatility of trading system $\mathrm{i}$ on the day $\mathrm{t}$; 
BAS $_{i, t-1}=$ Bid-ask spreads of trading system lagged one period;

$\mathrm{D}_{\mathrm{GLOBEX}}=$ Dummy variable is equal to one, for observations that belong to electronic trading spreads and equal to zero otherwise;

$e_{t}=$ Stationary time series error term.

All variables are expressed in logarithm form except for the dummy variable.

A negative relationship is expected between the bid-ask spreads and trading volume. As trading volume (a measure of market liquidity) increases, there is more opportunity for market makers to offset the undesirable positions of their inventories and hence reduce their price risk. Thus, bid-ask spreads will decrease. Intraday price volatility is expected to have a positive impact on the bid-ask spread because transaction price changes imply two types of risk for market makers. ${ }^{11}$ First, market makers may bear risk for holding excess inventory. Second, large price changes may be correlated with the presence of informed traders, and the dealer must increase spreads to compensate for expected loss when trading opposite informed traders. The one-period lagged bid-ask spread variable is used to capture the dynamic effect (specified as a partial-adjustment model) of bid-ask spreads and the coefficient is expected to be positive and less than one. We also add a tick-size dummy into the British Pound regression specification to control for the effects of tick-size reductions in British Pound futures on October 6, 2003. The dummy variable takes a value of 1 after the tick-size change and a value of 0 before the tick-size change.

Generalized Method of Moment is used to estimate the parameters of the covariance models of bid-ask spreads. The optimal weighted matrix used in the equation is the estimated consistent covariance matrix under the serially correlated and heteroskedastic error process (as proposed by Newey \&West, (1987)). The empirical 
results are reported in Table 2. As expected, the coefficients of trading volume for the Japanese Yen, British Pound, and Euro are negative and significant at least at the 5\% level. The coefficients of volatility are positive and significant for both Japanese Yen and British Pound futures and negative and insignificant for Euro futures. The coefficients of lagged bid-ask spreads are all positive and significant at the one percent level. This suggests that dynamic adjustment of the bid-ask spread is usually not completed in a oneday period for the futures contracts studied. For British Pound contracts, the coefficient of the tick-size change dummy is negative and significant as expected.

The coefficients of the GLOBEX dummy variable for the Japanese Yen, British Pound, and Euro futures are negative and significant at the one percent level. These results suggest that electronic trading spreads are lower than their corresponding floorbased spreads, even when we control for variation in spreads due to other related variables.

In sum, daily spreads are wider on the open-outcry trading system than on the electronic trading system for all contracts. These results are consistent with the hypothesis that the relative advantage of having a lower processing cost component of the spreads in the electronic trading system offsets the disadvantage of the large adverse information cost component that results from trader anonymity. ${ }^{12}$

\section{Price Discovery}

In this section, we first discuss the rationale for the existence of a co-integration system in FX futures, which are simultaneously traded on both open-outcry and electronic trading systems. The common factor weight approach proposed by Gonzalo and Granger (1995) and the information share approach suggested by Hasbrouck (1995) 
are applied to examine the contribution of information shares by the same foreign exchange futures trading under alternative trading systems during regular trading hours.

Electronically-traded FX futures prices and prices of their floor-traded counterparts contain a random walk component due to the efficient market hypothesis, and they are a non-stationary time series. They are trading for the same underlying asset. Thus, it is expected that they share the same implicit efficient price component (common stochastic trend) due to price arbitrage. Hence, the difference between the two price series will be stationary. Therefore, these prices in these two markets form a cointegration system. The co-integration system will have one co-integrating vector and one stochastic common trend.

If two prices are co-integrated, based on the Granger representation theorem (Engle and Granger 1987), their price changes should be represented by a vector error correction (VEC) model as

$$
\Delta p_{t}=\mu+\sum_{i=1}^{k} \Gamma_{i} \Delta p_{t-i}+\Pi p_{t-1}+\varepsilon_{t}
$$

where

$p_{t}$ are $2 \times 1$ vector of the $\log$ price changes, $\mu$ is $(2 \times 1)$ vector of constants, $\Gamma_{i}$ are (2x2) matrices of parameters, $\mathrm{k}$ is the lag length which will be determined by the AIC criteria, $\Pi=\alpha \beta^{\prime}$ is $(2 \times 2)$ matrix, $\alpha$ is $(2 \times 1)$ the adjustment parameter matrix and $\beta$ is a (2x1) co-integrating matrix and a row of $\beta^{\prime}$ is a co-integrating vector, $\varepsilon_{\mathrm{t}}$ is a $(2 \mathrm{x} 1)$ error vector with a mean zero vector and covariance matrix $\Omega, \Delta$ is the difference operator.

The Augmented Dickey-Fuller (ADF) test is employed to test the order of integration, and the lag length is chosen based on AIC Criteria and white noise of the 
residual. We find that intraday price series contain a unit root. ${ }^{13}$ As expected, they are non-stationary time series with an integrated order of one. We also apply Johansen's (1991) likelihood ratio test and the maximum eigenvalue test known as $\lambda_{\text {max }}$ to check each pair of the intraday series form a cointegrated system. The empirical results confirm that they form a cointegrated system for each matched pair of intraday transaction price series. $^{14}$

\subsection{Common Long Run Factor Weight}

In a co-integrated system such as in equation (2), Gonzalo and Granger (1995) propose a methodology to decompose the vector of market prices into permanent and transitory components:

$$
p_{t}=f_{t} i_{2}+z_{t}
$$

where $\mathrm{p}_{\mathrm{t}}$ is defined in equation (2), $\mathrm{f}_{\mathrm{t}}$ is a common long memory component and $\mathrm{z}_{\mathrm{t}}$ an (2x1) transitory component (i.e. $\mathrm{I}(0))$. $\mathrm{i}_{2}$ is an $(2 \mathrm{x} 1)$ unit vector.

They impose two restrictions which allow for identification of the common longmemory component $f_{t}$ : (1) $f_{t}$ is a liner combination of current market prices; and (2) the transitory component $z_{t}$ has no long run impact on market price $p_{t}$.

Using Johansen's maximum likelihood estimation framework, Gonzalo and Granger (1995) suggest that the common long memory factor can be estimated as $f_{t}=\alpha_{\perp}^{\prime} p_{t}$, where $\alpha_{\perp}^{\prime}$ is a $(2 \times 1)$ vector which is orthogonal to $\alpha$, the vector of speed adjustment of error correction term defined in equation (2). The common factor (common stochastic trend) has been interpreted as an implicit efficient price, which is common to the related market prices. The normalized factor weights are used as measures of the contribution to price discovery by each related market price. The factor weights 
are summed to one. The market with greater weight is considered to contribute more to the price discovery process. The common factor weights approach has been used by Theissen (2002) in assessing the relative price discovery contributions of trading the same stock on electronic versus floor trading systems in the German equity markets. ${ }^{15}$

We first estimate common factor weights for each day in our data period. The data set of daily estimates provides us with an opportunity to test the relationship between liquidity and the price discovery process. The time series behavior of the daily estimates of price discovery for the Japanese Yen, British Pound, and Euro are reported in Figures 2.a, 3.a, and 4.a respectively. It is interesting to observe that the common factor weights of the floor-traded Japanese Yen and British Pound are generally greater than their corresponding counterparts traded on GLOBEX during the calendar year 2003 sample period. For example, in the Japanese Yen market, the common factor weights of floortrading above 50 percent for the March 2003 contract month trading period occurred on 39 out of 45 days, while for the March 2004 contract month trading period, the common factor weights of floor trading exceeded 50 percent only on 25 days out of 60 days. This monotonically-decreasing trend also holds in British Pound and Euro exchange futures. In the British Pound market, the common factor weights of floor-trading greater than 50 percent occurred on 23 out of 46 days in the March 2003 contract month trading period, but decreased to 14 out of 60 days in the March 2004 contract month trading period. In the Euro FX market, GLOBEX trading dominated price discovery during the sample period. In the March 2003 contract month trading period, the common factor weights of GLOBEX trading above 50 percent occurred on 21 out of 45 days. During the March 
2004 contract month trading period, the factor weights of GLOBEX trading exceeding 50 percent occured on 50 out of 59 days.

Tables 3,4 , and 5 present the aggregate estimates of common factor weights for three contract month trading periods (i.e. March and September 2003, and March 2004) in mean, median and standard deviation of the three futures contracts trading on the floor versus GLOBEX. It is interesting to observe that, in the case of Japanese Yen and British Pounds, common factor weights of floor-based trading have trended downward over the sample period. For example, in the March 2003 contract trading period, floor trading in Japanese Yen and British Pounds accounts for 71 percent and 53 percent of price discovery respectively (see Tables 3A and 4A). In the March 2004 contract month trading period, common factor weights of floor trading in these two futures contracts have decreased to 49 percent and 42 percent respectively (see Tables $3 \mathrm{C}$ and $4 \mathrm{C}$ ). In the Euro FX case, the common factor weight for GLOBEX has exhibited an upward trend in its contribution to price discovery, from 55 per cent in mean in the March 2003 contract month trading period to 74 percent in mean in the March 2004 contract month sample trading period (see Table 5C).

\subsection{Hasbrouck Information Shares}

Hasbrouck (1995) defines price discovery as the arrival of new information that affects the permanent implicit common efficient price changes. He suggests that the contribution towards price discovery made by each market (sharing a stochastic common trend) is defined as the variation in efficient price innovations attributable to that market's innovation. If the majority of the total efficient prices variation is responsible by $\mathrm{j}^{\text {th }}$ market, then the $\mathrm{j}^{\text {th }}$ market is the major force in setting the common efficient price. 
In a cointegrated system, the VEC model in (1) has a common trend representation (i.e. infinite moving average representation, Johansen (1991)), ${ }^{16}$

$$
p_{t}=u_{0}+C \sum_{i=1}^{t} \varepsilon_{t}+C^{*}(L) \varepsilon_{t}
$$

where $\mathrm{u}_{0}$ is a constant $(2 \mathrm{x} 1)$ vector, $\mathrm{C}$ is the impact matrix, representing the long-run impact of disturbance on each of the two prices. $C^{*}(L)$ is a matrix polynomial in the lag operator.

If the variance covariance matrix $\Omega$ were diagonal, Hasbrouck (1995) defines the $\mathrm{j}^{\text {th }}$ market information share as

$$
S_{j}=\frac{c_{j}^{2} \Omega_{j j}}{c \Omega c^{\prime}}
$$

where $c_{j}$ is the $j^{\text {th }}$ element of the common row vector of the impact matrix $c$ in the common trend representation and $\Omega_{\mathrm{jj}}$ is the $\mathrm{j}^{\text {th }}$ diagonal element of $\Omega$.

When the covariance matrix $\Omega$ is not diagonal, Hasbrouck (1995) defines the information shares of the $\mathrm{j}^{\text {th }}$ market prices as:

$$
S_{j}=\frac{\left([c F]_{j}\right)^{2}}{c \Omega c^{\prime}}
$$

In equation (6), $\mathrm{F}$, the Cholesky factorization of $\Omega$, is a lower triangular matrix such that $\Omega=F F^{\prime}$. The variance attributed to a particular market $\mathrm{j}$ is $\left([\mathrm{cF}]_{\mathrm{j}}\right)^{2}$ and $[\mathrm{cF}]_{\mathrm{j}}$ is the $\mathrm{j}^{\text {th }}$ element of the row matrix $[\mathrm{cF}]$. The lower triangular factorization maximizes the information shares on the first price. By permuting the order of the market prices, equation (6) will provide an upper and lower bound for the information share of each 
market. We also use the midpoint of the upper and lower bounds of $\mathrm{j}^{\text {th }}$ markets as a single measure of $\mathrm{j}^{\text {th }}$ markets' information shares. ${ }^{17}$

Time series behaviors of the daily information shares of these three futures contracts trading in alternative systems are presented in Figures $2 b, 3 b$, and $4 b$. In the Japanese Yen and British Pound futures markets, the information shares of the floor trading system above 50 percent have exhibited a downward trend from the March 2003 contract month trading period to the March 2004 contract month trading period. For example, in the March 2003 contract month trading period, the information shares of floor trading in the Japanese Yen market are above 50 percent on 39 out of 45 days. In the March 2004, contract month trading period, there are only 25 out of 60 days where the information shares of floor trading are greater than 50 percent. In the Euro FX futures, the information shares of screen trading have experienced an upward trend. In the whole sample period, there are only 64 days where the information shares of floor trading are above 50 percent.

The aggregate measures of information shares (in mean, median and standard deviation) for three sub-contract periods are reported in Tables 3, 4, and 5. Again, the information shares of screen trading have experienced an upward trend for all three futures contracts. In the March 2004 contract month trading period, information shares of screen trading in all three contracts are greater than the information shares of floor trading in contributing to the price discovery process. During the 2003 sample period, the floor trading system in Japanese Yen and British Pound futures made a larger contribution to price discovery using information shares measures. In the Euro FX 
market, the contribution of floor trading towards price discovery is secondary for the whole sample period.

In summary, we provide empirical evidence that all three FX futures trading on the GLOBEX have exhibited an upward trend in its contribution to price discovery than floor trading. The empirical results produced by the information shares measure and the common factor weights measure are consistent with each other.

\subsection{Price Discovery in High and Low Volatility Periods}

To estimate screen traded foreign exchange futures' contribution to the price discovery process in high versus low volatility periods, we classify trading days into high, normal, and low volatility days. The procedure we used consists of three steps. First, the daily volatility of screen-traded and floor traded futures are estimated for each trading day. Second, we estimate the empirical distributions of daily volatility for each contract month trading period. Third, trading days during a given sample period are classified into high volatility days if their daily volatility is equal to or greater than the $90^{\text {th }}$ percentile of the empirical distribution of daily volatility for a given sample period, and are classified into low volatility days if their volatility is equal to or less than the 10th percentile of the empirical distribution for a given sample period. ${ }^{18}$

Table 6 presents the contribution to information shares (measured by common factor weights) by screen traded versus floor traded Japanese yen, British Pound and Euro FX futures markets during the high and low volatility periods of the March and September 2003 contract months and the March 2004 contract month. We observe three interesting results: (1) floor-trading in the Japanese Yen and British Pound futures markets makes a larger contribution to information shares during both high and low 
volatility periods than their screen-traded counterparts for the March and September 2003 contract months; (2) during the March 2004 contract month trading period, we observe that screen trading in British Pounds made a larger contribution to information shares than floor trading during both low and high volatility periods; (3) screen trading in Euro FX futures makes a larger contribution to information shares during both high and low volatility periods than floor trading; and (4) screen trading makes larger or equal contributions to information shares in the Japanese Yen, British Pound and Euro FX futures markets during low volatility periods compared with their contributions to information shares during high volatility periods. However, this pattern does not hold for screen trading in British Pound futures in the September 2003 contract month trading period. ${ }^{19}$

These results differ from the empirical findings by Martens (1998) and Franke and Hess (2000), who found that German Bund futures traded on DTB (screen traded) made a dominant contribution to price discovery during low price volatility periods, and a secondary contribution to price discovery during high volatility periods in comparison with German bund futures traded on LIFFE (floor trading).

\section{The Relationship between Price Discovery Measures and Liquidity}

Having estimated daily information shares and common factor weights over time, we would like to examine various liquidity measures affecting the daily variation of price discovery in these two futures markets in the following regression model framework:

$$
\mathrm{IS}_{\text {floor }}=\alpha_{0}+\alpha_{1} \mathrm{MS}_{\text {floor }}+\alpha_{2} \mathrm{RNTR}+\alpha_{3}\left(\mathrm{BAS}_{\text {floor }}-\mathrm{BAS}_{\text {screen }}\right)+\alpha_{4} \mathrm{Vlt}+\varepsilon
$$


where $\mathrm{IS}_{\text {floor }}$ denotes Hasbrouck's information share of floor-based trading systems. ${ }^{20}$ $\mathrm{MS}_{\text {floor }}$ is the market share of the floor-based trading system defined as the ratio of floorbased trading volume divided by the sum of the trading volume of electronic trading and floor-based trading systems (see Figure 5). RNTR is the relative market activity variable. The relative market activity is measured by the ratio of daily means of the number of floor trades per 3-minute periods to daily means of the number of screen trades per 3minute periods. ${ }^{21}$ Figure 6 presents the time series plots of daily means of trading frequency per 3-minutes for all six contracts. BAS floor denotes spreads of the floor and BAS $_{\text {screen }}$ denotes the spreads of the GLOBEX (see figure 1). Vlt denotes volatility of the floor.

Fleming, Ostdiek, and Whaley (1996) argue that trading cost is the major factor in explaining relative rates of price discovery in security futures and option markets. They also ascertained that price discovery will occur in the market with the lowest cost (liquid market), since informed traders choose to trade in that market. The bid-ask spread is a measure of trading cost. Narrower spreads mean lower trading costs. Since traders prefer to trade in a lower cost market, we expect that the coefficient of the variable, $\left(\mathrm{BAS}_{\text {floor }}-\mathrm{BAS}_{\mathrm{Globex}}\right)$, the difference between the two spreads, is negatively related to information shares of the floor trading system. It is expected that the sign of the coefficient of the market share of screen trading, $\mathrm{MS}_{\text {floor }}$ should be positive. Traders prefer to trade in liquid markets. ${ }^{22}$ The relative trading activity variable is another measure of liquidity and is expected to have a positive sign as well.

OLS is used to estimate the parameters of model (7). The Newey and West procedure (1987) is used to calculate consistent standard errors of regression parameter 
estimates under a serially correlated and heteroskedastic error process. Tables 7, 8 and 9 report coefficient estimates of the regressions for Japanese Yen, British Pound, and Euro futures. From the specification (1) of Table 7, we observe that the coefficients of the spread difference and market shares have expected signs and they are statistically significant as well in Japanese Yen futures. The relative market activity variable in regression specification (2) is insignificant but it becomes positive and significant after the market share variable is removed from the regression. This is because the relative market activity variable and market share variable have strong multicolinearity. In order to eliminate the multicolinearity effects among the alternative measures of liquidity, we estimate the impacts of each liquidity measure alone on information shares and the results are reported in specifications (4), (5) and (6) of Table 7. We observed that each liquidity variable has the expected sign and is statistically significant at least at the $5 \%$ level.

The specifications (1), (2) and (3) of Table 8 also report the regression results of the relationship between the alternative measures of liquidity and price discovery for British Pound futures under alternative trading systems. We find that the coefficient estimates on the market share of floor trading are positive, as expected, but statistically insignificant for the regression specification (1). The coefficients of the spread differentials are negative, as expected, but also statistically insignificant. However, the coefficients of the market activity variable are significant and have correct signs in both specifications (2) and (3). We again find that each liquidity variable has the correct sign and is statistically significant in specification (4), (5), and (6) of Table 8. We also control for tick size change in the British Pound futures and find that it has no effect on price discovery. 
Regression results of Euro FX futures are also reported in Table 9. In the specifications (1), (2), and (3) only the coefficients of relative spreads are negative and statistically significant. As the cost of trading goes up in floor trading, then price discovery will shift to the GLOBEX system. Again, results for the impacts of coefficient of each liquidity variable on information shares in Euro FX futures are similar to the results in Japanese Yen and British Pounds.

The coefficients of volatility are insignificant in Tables 7, 8, and 9. We fail to obtain evidence to support the hypothesis that the floor-based trading system makes a larger contribution towards the price discovery during high volatility periods in these foreign FX futures.

In short, each of the alternative three measures of liquidity is statistically significant in explaining the evolution of price discovery for these foreign FX futures. Our results are consistent with the hypothesis that the evolution of the price discovery process is related to the change in relative liquidity of floor trading versus screen trading systems over time.

\section{Summary and Conclusions}

This paper examines the relative liquidity and rate of price discovery for floor versus electronic trading in the CME's Japanese Yen, British Pound, and Euro FX futures markets, during a sample period extending from January 2, 2003 to March 5, 2004. We find that bid-ask spreads are higher for floor-based trading. These higher spreads may be due to the fact that floor trading systems may be less operationally efficient than screen trading systems. 
Based on common factor weights and information shares, we find that trading in both systems contribute to the price discovery process. The use of a longer sample period and daily estimates of information shares allows us to observe the evolution of price discovery contributions made by each trading system over time. For example, during the 2003 sample period, we found that trading under the open-outcry system had contributed relatively more to price discovery in the Japanese Yen and British Pound futures markets. However, beginning in calendar year 2004, the situation has changed and screen trading (on the GLOBEX system) has become the larger contributor to the price discovery process. In the Euro FX futures market, trading on GLOBEX has made a relatively greater contribution to price discovery than floor trading during the entire 2003-2004 sample period. Our empirical results obtained for the CME's three FX futures markets do not support the hypothesis suggested by Martens (1998) that the contribution to information shares by electronic trading systems is higher in low volatility periods and lower in high volatility periods. Rather, our regression results support the hypothesis that optional efficiency and relative liquidity jointly influence the variation in information shares and common factor weights over time.

To gain greater understanding of the factors affecting the choice of alternative trading systems, we would need to identify who the major users of these two systems are. $^{23}$ Unfortunately, at the present time, we can not pursue research on this issue based on publicly available data because the CFTC's Commitments of Traders Report does not report separately on the classification of non-commercials (speculators) versus commercials (hedgers) in floor-based versus screen-based systems. 
Screen-based and floor-based trading systems have coexisted in the CME's Japanese Yen, British Pound, and Euro FX futures markets for the last four years. Trading volume and open interest in these three exchange futures markets have enjoyed strong growth during our sample period. ${ }^{24}$ These factors indicate that the CME made the right decision to provide the opportunity for individual traders to trade under whichever trading system best met their particular trading needs. 


\section{Endnotes}

\footnotetext{
${ }^{1}$ About $95 \%$ of the E-mini trades were in units of less than five contracts, and many day traders use E-mini futures (Ates and Wang 2003).

${ }^{2}$ Shyy and Lee (1995) use data from November 8 to November 19, 1993 and Kofman and Moser (1997) use data from March 2 to April 10, 1992.

${ }^{3}$ Grunbichler et al. (1994) claim that fast execution reduces execution risk. Thus, electronic trading reduces the order processing cost and cost of trading.

${ }^{4}$ Further discussion is referred to Grunbicher, Longstaff and Schwartz (1994), Lucas and Shatz (2000) and Pirrong (1996).
}

${ }^{5}$ Massimb and Phelps (1994) present detailed discussion on the accessibility of timely market information on locals trading in the pits versus on the GLOBEX system. Beneviste, Marcus and Wilhelm (1992) discussed the advantages of specialists trading in the floor trading system.

${ }^{6}$ They provided empirical evidence to support their argument in the DTB (electronic trading) versus the LIFFE German Bund futures (floor trading) during the sample period from 1991 to 1995.

${ }^{7}$ Minimum tick size for the British Pound contracts changed to $\$ 6.25$ starting with GLOBEX trading on Sunday October 5, 2003, for the trade date of Monday, October 6, 2003. Before October 5, 2003, the minimum tick size was $\$ 12.50$.

${ }^{8}$ The basic idea for this procedure is suggested by Bhattacharya (1983) and is slightly modified by Wang, Moriarty, Michalski and Jordan (1991).

9 See Wang ( 1994), Wang (1997), Tse and Zabotina (2004) and others.

${ }^{10}$ It is desirable to perform the decomposition of bid-ask spread components in our analysis. Unfortunately we can not perform this analysis because US intraday futures data do not report bid-ask quotes.

11 The intraday price volatility variable is measured by $\ln$ (maximum price/minimum price) where the maximum and minimum prices are calculated each day during the regular trading hours (i.e. 7:20 a.m. to 2:00 p.m.).

12 Based on Triennial Central Bank Survey of Foreign Exchange and Derivatives Market Activity in April 2004 (published by Bank for International Settlements, Basel, Switzerland). Paul Dawson finds that average daily trading volume (\$billion) of Euro/USD futures markets account for less than three percent of average daily trading volume of the entire foreign exchange markets. Since informed traders like to trade in relatively liquid OTC and spot markets, he suggests that there is less probability of informed traders trading in FX futures markets.

${ }^{13}$ In order to save space, these results are not reported here, but interested readers can obtain the results from the authors.

${ }^{14}$ These empirical results are not reported here, but interested readers can obtain these results from the authors.

${ }^{15}$ Booth, So and Tse (1999) employ a common factor weight approach to study price discovery in the German equity derivatives markets. Harris, McInish and Wood (2002) apply this technique to study price discovery of Dow Jones' stocks trading on informationally-linked exchanges. Studies involving the 
application of common factor weights in the price discovery process include Covrig, Ding and Low (2004) , Frino, Harris, McInish and Tomas III (2004) and others.

${ }^{16}$ Further discussion on the stochastic trend representation of a cointegrated system may be found in Stock and Watson (1988).

${ }^{17}$ Ballie, Booth, Tse and Zabotina (2003) demonstrate that the mean of the upper and lower bounds of information shares is a reasonable measure of a market's contribution to the price discovery process.

${ }^{18}$ We follow the rule suggested by Webb and Smith (1994) and Martens (1998) to classify trading days into high and low volatility days.

${ }^{19}$ We find similar results for contribution shares (measured by Hasbrouck's information shares) by screen versus flooring trading in these three FX futures markets. In order to save space, we do not report them here, but they are available from the authors upon request.

${ }^{20}$ Since the regression results of determinants on the two price discovery measures--common factor weights and information shares--are similar, we only report the regression results with dependent variables measured by Hasbrouck's information shares (1995).

${ }^{21}$ The number of trades per 3-minute period is calculated for each day. Then, the daily means of the number of trades per 3-minute interval are used in computing the ratio of the number of floor trades to screen trades.

${ }^{22}$ Stephan and Whaley (1990) examine the relationship between intraday price change and trading volume in the stock and stock options markets. Their findings suggest that price discovery and trading activity are related.

${ }^{23}$ Based on trade size distributions of these three markets (see table A2 in the appendix), we find the percentage of one contract trades is higher in screen trading than in floor trading. On the other hand, the percentage of trade size larger than nine contracts is greater in floor trading than in screen trading in Euro FX Futures markets. This suggests that different traders may prefer different trading systems. Harris (2003, Chapter 26) gives an excellent discussion on trader's choice of alternative trading systems to satisfy their differences in trading needs.

${ }^{24}$ The one year growth rates for trading volume for the period 2000 to 2001 are $2.4 \%$ (British Pounds), $14.8 \%$ (Japanese Yen) and 7.12\% (Euro FX), respectively. The one year growth rates for the period 2003 to 2004 are $80.2 \%$ (British Pounds), 21.52\% (Japanese Yen) and $82.74 \%$ ( Euro FX), respectively. We found similar growth rates patterns for open interest for these FX futures contracts as well. 


\section{References}

Aitken, M. J., A. Frino, E. Jarnecic, and A.H. Hill, (2004) "The Impact of Electronic Trading on Bid-Ask Spreads: Evidence from Futures Markets in Hong Kong, London and Sydney," The Journal of Futures Market, 24, 675-696

Amihud, Y. and H. Mendelson, (1987), "Trading Mechanisms and Stock Returns: An Empirical Investigation,” Journal of Finance, 42, 533-553.

Ates, A. and G. H. K. Wang (2003) "Information Transmission in Electronic versus Open-Outcry Trading Systems: An Analysis of U.S. Equity Futures", Presented at Financial Management Association Meeting in Denver, October 2003 and the Journal of Futures Markets (2005) Forthcoming.

Baillie, R. T., G. G. Booth, Y. Tse, and T. V. Zabotina (2002) "Price Discovery and Common Factor Models" Journal of Financial Markets, 5, 309-321.

Beneviste, L., A. J. Marcus, and W. J. Wilhelm (1992) "What's Special about the Specialist?” Journal of Financial Economics, 32, 61-86.

Bollen, B. and Inder, B. (2002) "Estimating Daily Volatility in Financial Markets Utilizing Intraday Data." Journal of Empirical Finance, 9, 551-562.

Booth, G.G., R. W. So, and Y. Tse (1999) "Price Discovery in the German Equity Index Derivative Markets.” The Journal of Futures Markets, 19, 619-643.

Coppejans, M. and I. Domowitz (1999), "Price Behavior in an off-hours Computerized Market” Journal of Empirical Finance, 6, 583-607.

Covrig, V., D. K. Ding and B.S. Low (2004) "The Contribution of a Satellite Market To Price Discovery: Evidence from the Singapore Exchange" Journal of Futures Markets, 24, 10, 981-1004.

De Jong, F. (2002) "Measures of Contributions to Price Discovery: A Comparison" Journal of Financial Markets, 5, 323-327.

Engle, R. F. and C.W. J. Granger (1987) "Co-integration and Error Correction: Representation, Estimation, and Testing," Econometrica 55, 251-276.

Fleming, J., B. Ostdiek, and R. E. Whaley (1996) "Trading Costs and the Relative Rate of Price Discovery in Stock, Futures, and Option Markets," The Journal of Futures Markets, 16, 353-387.

Franke,G. and D. Hess, (2000) "Information Diffusion in Electronic and Floor Trading," Journal of Empirical Finance, 7, 455-478. 
Frino, A., T. H. McInish, and M. Toner (1998) "The Liquidity of Automated Exchanges: New Evidence from German Bund Futures," Journal of International Financial Markets, Institutions and Money 8, 225-241.

Frino, A, F. H. Harris, T. H. McInish and M.J. Tomas III (2004) "Price Discovery in the Pits: The Role of Market Makers On the CBOT and Sydney Futures Exchange" The Journal of Futures Markets, 24, 8, 785-804.

Fuller, W. A. (1996) Introduction to Statistical Time Series (2 ${ }^{\text {nd }}$ ed.). New York: John Wiley.

Gilbert, C.L. and H.A. Rijken (2003) "How is Futures Trading Affected by the Move to A Computerized Trading System? Lessons from LIFFE FTSE 100 Contract" Working Paper, Vrije University, Amsterdam, the Netherlands.

Glosten, L. (1994) “Is the Electronic Limit Order Book Inevitable?” Journal of Finance, 49, 1127-1161.

Gonzalo, J. and C.W. J. Granger (1995) "Estimation of Common Long-Memory Components in Co-integrated Systems." Journal of Business and Economic Statistics, 13, 27-36.

Grunbichler, A., F. A. Longstaff, and E. S. Schwartz (1994) "Electronic Screen Trading and the Transmission of Information: An Empirical Examination," Journal of Financial Intermediation, 3,166-187.

Harris, F. H., T. H. McInish, G. L. Shoesmith, and R. A. Wood (1995) "Cointegration, Error Correction, and Price Discovery on Informationally Linked Security Markets." Journal of Financial and Quantitative Analysis, 30, 563-579.

Harris, F. H., T. H. McInish, and R. A. Wood (2002) "Security Price Adjustment across Exchanges: An Investigation of Common Factor Components of Dow Stocks." Journal of Financial Markets, 5, 277-308.

Harris, L. E. (2003), Trading and Exchanges, New York, Oxford University Press Hasbrouck, J. (1995) "One Security, Many Markets: Determining the Contributions to Price Discovery” Journal of Finance 50,1175-1199.

Hasbrouck, J. (2003) "Intraday Price Formation in US Equity Index Market," Journal of Finance, 58(6), 2375-2399.

Kofman, P. and J. T. Moser (1997) "Spreads, Information Flows and Transparency Across Trading Systems," Applied Financial Economics, 7, 281-294. 
Johansen, S. (1991) "Estimation and Hypothesis Testing for Cointegrating Vectors in Gaussian Vector Autoregressive Models," Econometrica, 59, 1551-1580.

Kurov, A. and D. Lasser (2002) "Price Discovery in the E-mini Futures Markets: Is the Tail Wagging the Dog?" Presented at Financial Management Annual Meeting, San Antonio, Texas, October 2002.

Martens, M. (1998) "Price Discovery in High and Low Volatility Periods: Open Outcry versus Electronic Trading," Journal of International Financial Markets, Institutions and Money, 8, 243-260.

Massimb M. N. and B. D. Phelps (1994) "Electronic Trading, Market Structure and Liquidity," Financial Analysts Journal, 39- 50.

Miller, M.H. (1990) "International Competitiveness of U. S. Futures Exchanges," Journal of Financial Services Research, 4, 387-408.

Newey, W. K. and K. D. West (1987) "A Simple Positive Semi-Definite Heteroskedasiticity and Autocorrelation Consistent Covariance Matrix," Econometrica $55,703-708$.

Pirrong, C. (1996) "Market Liquidity and Depth on Computerized and Open Outcry Trading Systems: A Comparison of DTB and LIFFE Bund Contracts," The Journal of Futures Markets 16, 519-543.

Pirrong, C. (2003) "Upstairs, Downstairs: Electronic vs Open Outcry Exchanges" Working paper, Department of Economics, University of Houston.

Schmidt, H. and P. Iversen (1992) "Automating German Equity Trading: Bid-ask Spreads on Competing Systems," Journal of Financial Services Research, 15, 373-92.

Shyy, G. and J. H. Lee (1995) "Price Transmission and Information Asymmetry in Bund Futures Markets: LIFFE vs DTB," The Journal of Futures Markets, 15, 87-89.

Stephan, J. A. and Whaley, R. E. (1990) "Intraday Price Change and Trading Volume Relations in Stock and Stock Option Markets," Journal of Finance, 45, 191-220.

Theissen, E. (2002) "Price Discovery in Floor and Screen Trading Systems." Journal of Empirical Finance, 9, 455-474.

Tse, Y. and T.V. Zabotina (2004) "Do Designed Market markers Improve Liquidity in Open Outcry Futures Markets," The Journal of Futures Markets, 24, 479-502.

Turkington, J. and D. Walsh (1999) "Price Discovery and Causality in the Australian Share Price Index Futures Markets," Australian Journal of Management, 24, 97-113. 
Wang, G. H. K., R. J. Michalski, J. V. Jordan, and E. J. Moriarty (1994), “An Intraday Analysis of Bid-Ask Spreads and Price Volatility in the S\&P 500 Index Futures Market," The Journal of Futures Markets, 14, 837-859.

Wang, G.H. K. and J. Yau (2000), "Trading Volume and Bid-Ask Spread and Price Volatility in Futures Markets." The Journal of Futures Markets, 20(10) 943-970.

Webb, R.I. and Smith, D.G. (1994) "The Effects of Market Opening and Closing on Volatility of Eurodollar Futures Prices.” Journal of Futures Markets, 14, 51-78. 
Table1. Summary Statistics Bid-Ask Spread*

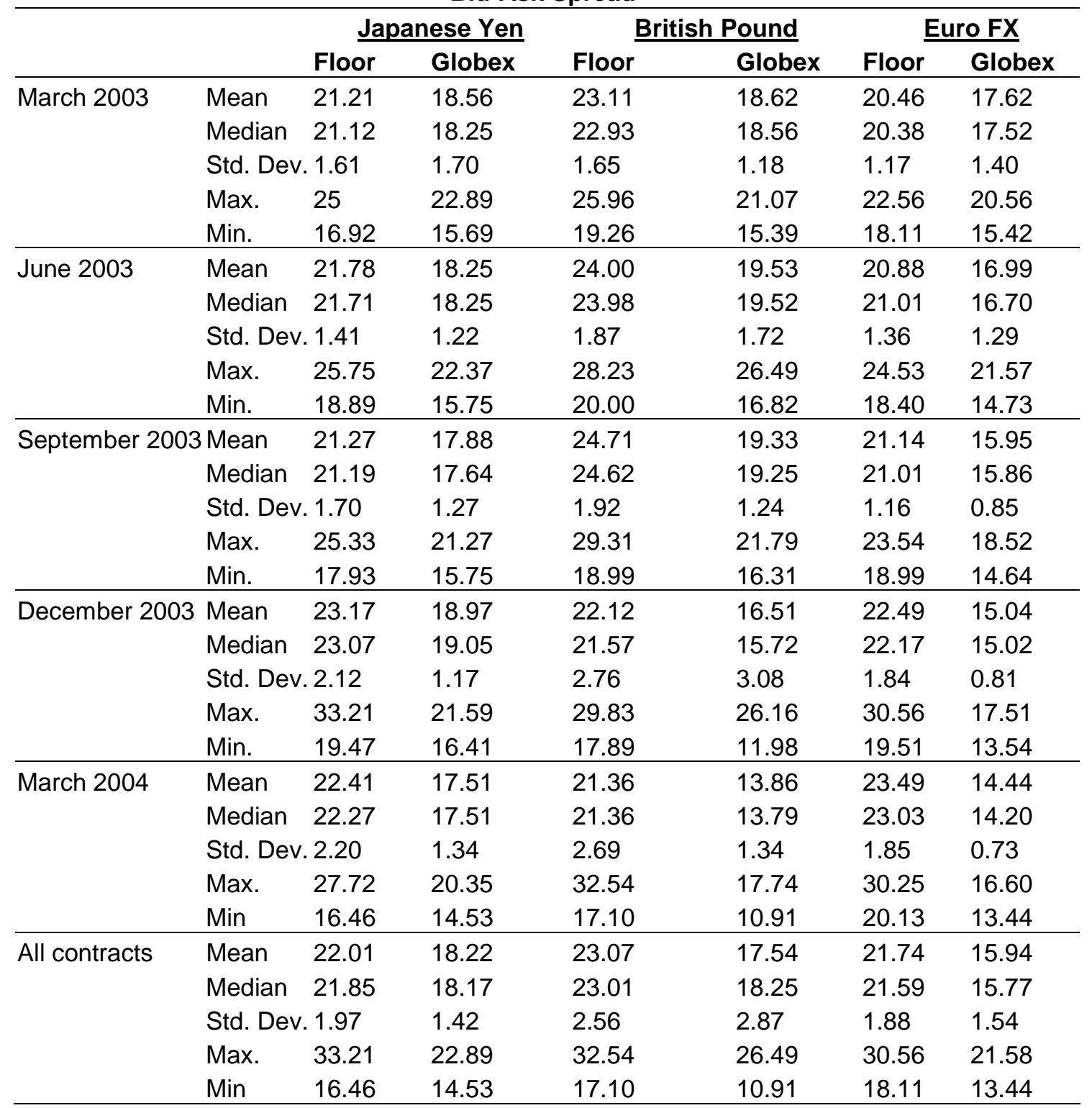

Note: * US Dollar per contract. 
Table 2 Bid-Ask Spread Regression Results

\begin{tabular}{lccc}
\hline & BAS JYEN & BAS $_{\text {BPOUND }}$ & BAS $_{\text {EFX }}$ \\
\hline Constant & $2.8314^{*}$ & $1.7336^{*}$ & $1.6566^{*}$ \\
& $(16.33)$ & $(10.21)$ & $(7.14)$ \\
$\mathrm{TV}_{\mathrm{t}}$ & $-0.0572^{*}$ & $-0.0533^{*}$ & $-0.0254^{*}$ \\
& $(-5.57)$ & $(-3.51)$ & $(-2.62)$ \\
$\mathrm{IV}_{\mathrm{t}}$ & $15.0481^{*}$ & $8.5743^{*}$ & -0.0054 \\
& $(7.54)$ & $(3.33)$ & $(-0.10)$ \\
BAS $_{\mathrm{t}-1}$ & 0.2078 & $0.5514^{*}$ & $0.5347^{*}$ \\
& $(5.12)$ & $(16.16)$ & $(8.93)$ \\
$\mathrm{D}_{\mathrm{GLOBEX}}$ & $-0.1388^{*}$ & $-0.0648^{*}$ & $-0.1226^{*}$ \\
$\mathrm{D}_{\text {TICK }}$ & $(-11.40)$ & $(-5.24)$ & $(-6.53)$ \\
& \multicolumn{3}{c}{$-0.0480^{* *}$} \\
$\mathrm{R}^{2}$ & $(-2.36)$ \\
\hline \multicolumn{4}{c}{0.72} \\
Note:
\end{tabular}


Table 3.A Price Discovery in the Japanese Yen Futures

March 2003 Contract

\begin{tabular}{|c|c|c|c|c|c|c|}
\hline \multicolumn{7}{|c|}{ Gonzalo and Granger's Common Factor Weights } \\
\hline & \multicolumn{3}{|c|}{ Floor Trading Price } & \multicolumn{3}{|c|}{ Globex Trading Price } \\
\hline Mean & \multicolumn{3}{|c|}{0.7135} & \multicolumn{3}{|c|}{0.2865} \\
\hline Median & \multicolumn{3}{|c|}{0.7245} & \multicolumn{3}{|c|}{0.2755} \\
\hline St. dev. & \multicolumn{3}{|c|}{0.1630} & \multicolumn{3}{|c|}{0.1630} \\
\hline \multicolumn{7}{|c|}{ Hasbrouck's Information Shares } \\
\hline & \multicolumn{3}{|c|}{ Floor Trading Price } & \multicolumn{3}{|c|}{ Globex Trading Price } \\
\hline & $\underline{\text { Min }}$ & $\underline{\text { Max }}$ & Midpoint & $\underline{\text { Min }}$ & $\underline{\text { Max }}$ & Midpoint \\
\hline Mean & $0 . \overline{4211}$ & 0.9032 & 0.6622 & 0.0968 & $0 . \overline{5789}$ & 0.3378 \\
\hline Median & 0.4131 & 0.9422 & 0.6642 & 0.0578 & 0.5869 & 0.3358 \\
\hline St. dev. & 0.1954 & 0.0966 & 0.1297 & 0.0966 & 0.1954 & 0.1297 \\
\hline
\end{tabular}

Note: Statistics are based on a VEC model of futures estimated at a 30 second resolution. The model is estimated for each trading day in the sample. The table presents summary statistics for daily estimates of price discovery measures.

Table 3.B Price Discovery in the Japanese Yen Futures

September 2003 Contract

\begin{tabular}{|c|c|c|c|c|c|c|}
\hline \multicolumn{7}{|c|}{ Gonzalo and Granger's Common Factor Weights } \\
\hline & \multicolumn{3}{|c|}{ Floor Trading Price } & \multicolumn{3}{|c|}{ Globex Trading Price } \\
\hline Mean & \multicolumn{3}{|c|}{0.6160} & \multicolumn{3}{|c|}{0.3840} \\
\hline Median & \multicolumn{3}{|c|}{0.6172} & \multicolumn{3}{|c|}{0.3828} \\
\hline St. dev. & \multicolumn{3}{|c|}{0.1749} & \multicolumn{3}{|c|}{0.1749} \\
\hline \multicolumn{7}{|c|}{ Hasbrouck's Information Shares } \\
\hline & \multicolumn{3}{|c|}{ Floor Trading Price } & \multicolumn{3}{|c|}{ Globex Trading Price } \\
\hline & $\underline{\text { Min }}$ & Max & Midpoint & $\underline{\text { Min }}$ & $\underline{\text { Max }}$ & Midpoint \\
\hline Mean & $0 . \overline{3311}$ & $0 . \overline{8411}$ & 0.5861 & $0 . \overline{1589}$ & $0 . \overline{6689}$ & 0.4139 \\
\hline Median & 0.3004 & 0.8833 & 0.5832 & 0.1167 & 0.6996 & 0.4168 \\
\hline St. dev. & 0.1893 & 0.1511 & 0.1521 & 0.1151 & 0.1983 & 0.1521 \\
\hline
\end{tabular}

Note: Statistics are based on a VEC model of futures estimated at a 30 second resolution. The model is estimated for each trading day in the sample. The table presents summary statistics for daily estimates of price discovery measures.

Table 3.C Price Discovery in the Japanese Yen Futures March 2004 Contract

\begin{tabular}{lcc}
\hline \multicolumn{3}{c}{ Gonzalo and Granger's Common Factor Weights } \\
\hline & \multicolumn{1}{c}{ Floor Trading Price } & Globex Trading Price \\
Mean & 0.4989 & 0.5011 \\
Median & 0.4975 & 0.5025 \\
St. dev.S & 0.2019 & 0.2019 \\
\hline
\end{tabular}

Hasbrouck's Information Shares

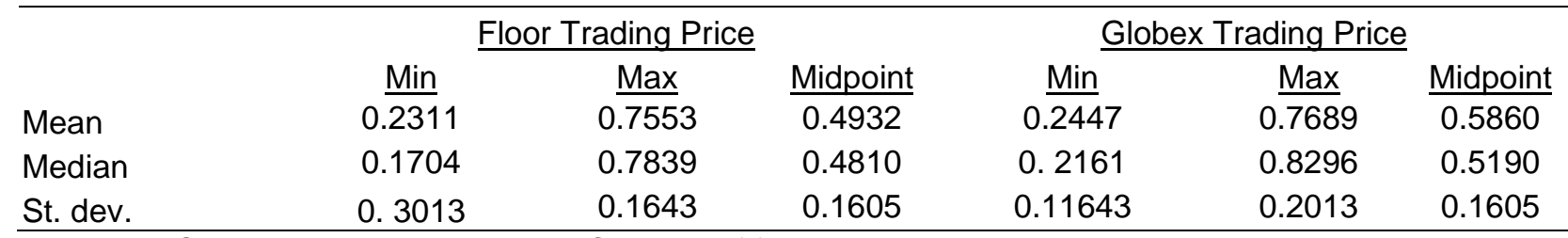

Note: Statistics are based on a VEC model of futures estimated at a 30 second resolution. The model is estimated for each trading day in the sample. The table presents summary statistics for daily estimates of price discovery measures. 
Table 4.A Price Discovery in the British Pound Futures

March 2003 Contract

\begin{tabular}{|c|c|c|c|c|c|c|}
\hline \multicolumn{7}{|c|}{ Gonzalo and Granger's Common Factor Weights } \\
\hline & \multicolumn{3}{|c|}{ Floor Trading Price } & \multicolumn{3}{|c|}{ Globex Trading Price } \\
\hline Mean & \multicolumn{3}{|c|}{05301} & \multicolumn{3}{|c|}{0.4699} \\
\hline Median & \multicolumn{3}{|c|}{05023} & \multicolumn{3}{|c|}{0.4977} \\
\hline St. dev. & \multicolumn{3}{|c|}{0.2399} & \multicolumn{3}{|c|}{0.2399} \\
\hline \multicolumn{7}{|c|}{ Hasbrouck's Information Shares } \\
\hline & \multicolumn{3}{|c|}{ Floor Trading Price } & \multicolumn{3}{|c|}{$\underline{\text { Globex Trading Price }}$} \\
\hline & $\underline{\text { Min }}$ & Max & Midpoint & $\underline{\text { Min }}$ & Max & Midpoint \\
\hline Mean & $0 . \overline{2906}$ & $0 . \overline{7509}$ & 0.5207 & $0 . \overline{249} 1$ & $0 . \overline{7094}$ & 0.4793 \\
\hline Median & 0.2238 & 0.7679 & 0.4942 & 0.2321 & 0.7762 & 0.5058 \\
\hline St. dev. & 0.2420 & 0.1785 & 0.11995 & 0.1785 & 0.2420 & 0.1995 \\
\hline
\end{tabular}

Note: Statistics are based on a VEC model of futures estimated at a 30 second resolution. The model is estimated for each trading day in the sample. The table presents summary statistics for daily estimates of price discovery measures.

Table 4.B Price Discovery in the British Pound Futures

September 2003 Contract

\begin{tabular}{|c|c|c|c|c|c|c|}
\hline \multicolumn{7}{|c|}{ Gonzalo and Granger's Common Factor Weights } \\
\hline & \multicolumn{3}{|c|}{ Floor Trading Price } & \multicolumn{3}{|c|}{ Globex Trading Price } \\
\hline Mean & \multicolumn{3}{|c|}{0.5804} & \multicolumn{3}{|c|}{0.4196} \\
\hline Median & \multicolumn{3}{|c|}{0.5405} & \multicolumn{3}{|c|}{0.4595} \\
\hline St. dev. & \multicolumn{3}{|c|}{0.1744} & \multicolumn{3}{|c|}{0.1744} \\
\hline \multicolumn{7}{|c|}{ Hasbrouck's Information Shares } \\
\hline & \multicolumn{3}{|c|}{ Floor Trading Price } & \multicolumn{3}{|c|}{ Globex Trading Price } \\
\hline & $\underline{\text { Min }}$ & Max & Midpoint & $\underline{\text { Min }}$ & Max & Midpoint \\
\hline Mean & $0 . \overline{3348}$ & $0 . \overline{7919}$ & 0.5633 & $0 . \overline{2081}$ & 0.6652 & 0.4367 \\
\hline Median & 0.2834 & 0.7888 & 0.5244 & 0.2112 & 0.7166 & 0.4756 \\
\hline St. dev. & 0.1973 & 0.1299 & 0.1555 & 0.1299 & 0.1973 & 0.1555 \\
\hline
\end{tabular}

Note: Statistics are based on a VEC model of futures estimated at a 30 second resolution. The model is estimated for each trading day in the sample. The table presents summary statistics for daily estimates of price discovery measures.

Table 4.C Price Discovery in the British Pound Futures March 2004 Contract

\begin{tabular}{lcc}
\hline \multicolumn{3}{c}{ Gonzalo and Granger's Common Factor Weights } \\
\hline Mean & Floor Trading Price & Globex Trading Price \\
Median & 0.4274 & 0.5726 \\
St. dev.S & 0.4178 & 0.5822 \\
\hline
\end{tabular}

Hasbrouck's Information Shares

\begin{tabular}{|c|c|c|c|c|c|c|}
\hline & \multicolumn{3}{|c|}{ Floor Trading Price } & \multicolumn{3}{|c|}{ Globex Trading Price } \\
\hline & $\underline{\text { Min }}$ & $\underline{\operatorname{Max}}$ & Midpoint & $\underline{\text { Min }}$ & Max & Midpoint \\
\hline Mean & $0 . \overline{1597}$ & $0 . \overline{7291}$ & 0.4444 & $0 . \overline{2709}$ & 0.8403 & 0.5556 \\
\hline Median & 0.0996 & 0.7474 & 0.4303 & 0.2526 & 0.9004 & 0.5697 \\
\hline St. dev. & 0.1960 & 0.1607 & 0.1592 & 0.1607 & 0.1960 & 0.1592 \\
\hline
\end{tabular}

Note: Statistics are based on a VEC model of futures estimated at a 30 second resolution. The model is estimated for each trading day in the sample. The table presents summary statistics for daily estimates of price discovery measures. 
Table 5.A Price Discovery in the Euro FX Futures

March 2003 Contract

\begin{tabular}{|c|c|c|c|c|c|c|}
\hline \multicolumn{7}{|c|}{ Gonzalo and Granger's Common Factor Weights } \\
\hline & \multicolumn{3}{|c|}{ Floor Trading Price } & \multicolumn{3}{|c|}{ Globex Trading Price } \\
\hline Mean & \multicolumn{3}{|c|}{0.4573} & \multicolumn{3}{|c|}{0.5427} \\
\hline Median & \multicolumn{3}{|c|}{0.4894} & \multicolumn{3}{|c|}{0.5106} \\
\hline St. dev. & \multicolumn{3}{|c|}{0.2139} & \multicolumn{3}{|c|}{0.2139} \\
\hline \multicolumn{7}{|c|}{ Hasbrouck's Information Shares } \\
\hline & \multicolumn{3}{|c|}{ Floor Trading Price } & \multicolumn{3}{|c|}{ Globex Trading Price } \\
\hline & $\underline{\text { Min }}$ & $\underline{\operatorname{Max}}$ & Midpoint & $\underline{\text { Min }}$ & $\underline{\operatorname{Max}}$ & Midpoint \\
\hline Mean & 0.1560 & 0.8266 & 0.4913 & 0.1734 & 0.8440 & 0.5087 \\
\hline Median & 0.1223 & 0.8632 & 0.4945 & 0.1368 & 0.8777 & 0.5050 \\
\hline St. dev. & 0.1614 & 0.1283 & 0.1263 & 0.1283 & 0.1614 & 0.1263 \\
\hline
\end{tabular}

Note: Statistics are based on a VEC model of futures estimated at a 30 second resolution. The model is estimated for each trading day in the sample. The table presents summary statistics for daily estimates of price discovery measures.

Table 5.B Price Discovery in the Euro FX Futures September 2003 Contract

\begin{tabular}{|c|c|c|c|c|c|c|}
\hline \multicolumn{7}{|c|}{ Gonzalo and Granger's Common Factor Weights } \\
\hline & \multicolumn{3}{|c|}{ Floor Trading Price } & \multicolumn{3}{|c|}{ Globex Trading Price } \\
\hline Mean & \multicolumn{3}{|c|}{0.3019} & \multicolumn{3}{|c|}{0.6891} \\
\hline Median & \multicolumn{3}{|c|}{0.2897} & \multicolumn{3}{|c|}{0.7103} \\
\hline St. dev. & \multicolumn{3}{|c|}{0.2037} & \multicolumn{3}{|c|}{0.2037} \\
\hline \multicolumn{7}{|c|}{ Hasbrouck's Information Shares } \\
\hline & \multicolumn{3}{|c|}{ Floor Trading Price } & \multicolumn{3}{|c|}{ Globex Trading Price } \\
\hline & $\underline{\text { Min }}$ & $\underline{\text { Max }}$ & Midpoint & $\underline{\text { Min }}$ & $\underline{\text { Max }}$ & Midpoint \\
\hline Mean & 0.0758 & 0.7083 & 0.3920 & 0.2917 & 0.9242 & 0.6080 \\
\hline Median & 0.0429 & 0.7533 & 0.3977 & 0.2467 & 0.9571 & 0.6023 \\
\hline St. dev. & 0.1292 & 0.2014 & 0.1418 & 0.2014 & 0.1292 & 0.1418 \\
\hline
\end{tabular}

Note: Statistics are based on a VEC model of futures estimated at a 30 second resolution. The model is estimated for each trading day in the sample. The table presents summary statistics for daily estimates of price discovery measures.

Table 5.C Price Discovery in the Euro FX Futures March 2004 Contract

\begin{tabular}{|c|c|c|}
\hline \multicolumn{3}{|c|}{ Gonzalo and Granger's Common Factor Weights } \\
\hline & Floor Trading Price & Globex Trading Price \\
\hline Mean & 0.2623 & 0.7377 \\
\hline Median & 0.1993 & 0.8007 \\
\hline St. dev.S & 0.2402 & 0.2402 \\
\hline
\end{tabular}

Hasbrouck's Information Shares

\begin{tabular}{|c|c|c|c|c|c|c|}
\hline & \multicolumn{3}{|c|}{$\underline{\text { Floor Trading Price }}$} & \multicolumn{3}{|c|}{ Globex Trading Price } \\
\hline & Min & Max & Midpoint & Min & Max & Midpoint \\
\hline Mean & $0 . \overline{0732}$ & $0 . \overline{6532}$ & 0.3633 & $0 . \overline{3468}$ & $0 . \overline{926} 7$ & 0.6367 \\
\hline Median & 0.0190 & 0.6763 & 0.3499 & 0.3237 & 0.9810 & 0.6501 \\
\hline St. dev. & 0.1741 & 0.1993 & 0.1459 & 0.1993 & 0.1741 & 0.1459 \\
\hline
\end{tabular}

Note: Statistics are based on a VEC model of futures estimated at a 30 second resolution. The model is estimated for each trading day in the sample. The table presents summary statistics for daily estimates of price discovery measures. 
Table 6 Price Discovery during High and Low Volatility Periods

a. Japanese Yen Futures

\begin{tabular}{|c|c|c|}
\hline $\begin{array}{l}\text { Low Volatility Period } \\
\text { Normal Period } \\
\text { High Volatility Period }\end{array}$ & $\begin{array}{c}\text { Japanese Yen-Floor Trading } \\
\text { Information Shares } \\
0.6070 \\
0.6666 \\
0.6760 \\
\end{array}$ & $\begin{array}{c}\text { Japanese Yen-Floor Trading } \\
\text { Common Factor Weights } \\
0.6787 \\
0.7178 \\
0.7091 \\
\end{array}$ \\
\hline $\begin{array}{l}\text { September } 2003 \text { Contract } \\
\text { Low Volatility Period } \\
\text { Normal Period } \\
\text { High Volatility Period } \\
\end{array}$ & $\begin{array}{c}\text { Japanese Yen-Floor Trading } \\
\text { Information Shares } \\
0.6154 \\
0.5784 \\
0.6098 \\
\end{array}$ & $\begin{array}{c}\text { Japanese Yen-Floor Trading } \\
\text { Common Factor Weights } \\
0.6248 \\
0.6102 \\
0.6516 \\
\end{array}$ \\
\hline $\begin{array}{l}\text { March } 2004 \text { Contract } \\
\text { Low Volatility Period } \\
\text { Normal Period } \\
\text { High Volatility Period }\end{array}$ & $\begin{array}{c}\text { Japanese Yen-Floor Trading } \\
\text { Information Shares } \\
0.5739 \\
0.4848 \\
0.4791\end{array}$ & $\begin{array}{c}\text { Japanese Yen-Floor Trading } \\
\text { Common Factor Weights } \\
0.5801 \\
0.4942 \\
0.4554\end{array}$ \\
\hline $\begin{array}{l}\text { March } 2003 \text { Contract } \\
\text { Low Volatility Period } \\
\text { Normal Period } \\
\text { High Volatility Period } \\
\end{array}$ & $\begin{array}{c}\text { b. British Pound Fut } \\
\text { British Pound-Floor Trading } \\
\text { Information Shares } \\
0.6190 \\
0.4879 \\
0.7341 \\
\end{array}$ & $\begin{array}{c}\text { British Pound -Floor Trading } \\
\text { Common Factor Weights } \\
0.6296 \\
0.4953 \\
0.7607 \\
\end{array}$ \\
\hline $\begin{array}{l}\text { September } 2003 \text { Contract } \\
\text { Low Volatility Period } \\
\text { Normal Period } \\
\text { High Volatility Period } \\
\end{array}$ & $\begin{array}{c}\text { British Pound-Floor Trading } \\
\text { Information Shares } \\
0.4982 \\
0.5783 \\
0.5150 \\
\end{array}$ & $\begin{array}{c}\text { British Pound -Floor Trading } \\
\text { Common Factor Weights } \\
0.5028 \\
0.5984 \\
0.5206 \\
\end{array}$ \\
\hline $\begin{array}{l}\text { March } 2004 \text { Contract } \\
\text { Low Volatility Period } \\
\text { Normal Period } \\
\text { High Volatility Period } \\
\end{array}$ & $\begin{array}{c}\text { British Pound-Floor Trading } \\
\text { Information Shares } \\
0.3841 \\
0.4524 \\
0.4406 \\
\end{array}$ & $\begin{array}{c}\text { British Pound -Floor Trading } \\
\text { Common Factor Weights } \\
0.3790 \\
0.4357 \\
0.4110 \\
\end{array}$ \\
\hline March 2003 Contract & $\begin{array}{c}\text { c. Euro FX Future } \\
\text { Euro FX-Floor Trading }\end{array}$ & Euro FX -Floor Trading \\
\hline $\begin{array}{l}\text { Low Volatility Period } \\
\text { Normal Period } \\
\text { High Volatility Period }\end{array}$ & $\begin{array}{c}\text { Information Shares } \\
0.4397 \\
0.5008 \\
0.4644\end{array}$ & $\begin{array}{c}\text { Common Factor Weights } \\
0.3667 \\
0.4723 \\
0.4218\end{array}$ \\
\hline $\begin{array}{l}\text { September } 2003 \text { Contract } \\
\text { Low Volatility Period } \\
\text { Normal Period } \\
\text { High Volatility Period }\end{array}$ & $\begin{array}{c}\text { Euro FX-Floor Trading } \\
\text { Information Shares } \\
0.3282 \\
0.4110 \\
0.2918\end{array}$ & $\begin{array}{c}\text { Euro FX -Floor Trading } \\
\text { Common Factor Weights } \\
0.2062 \\
0.3253 \\
0.1945 \\
\end{array}$ \\
\hline $\begin{array}{l}\text { Low Volatility Period } \\
\text { Normal Period } \\
\text { High Volatility Period }\end{array}$ & $\begin{array}{c}\text { Euro FX-Floor Trading } \\
\text { Information Shares } \\
0.2622 \\
0.3830 \\
0.2892 \\
\end{array}$ & $\begin{array}{c}\text { Euro FX -Floor Trading } \\
\text { Common Factor Weights } \\
0.1649 \\
0.2931 \\
0.0976\end{array}$ \\
\hline
\end{tabular}


Table 7. Regression Analysis of Factors Affecting the Contribution to Price Discovery Process in Japanese Yen Futures Markets

\begin{tabular}{|c|c|c|c|c|c|c|}
\hline \multirow[b]{2}{*}{ Dependent Variable } & \multicolumn{6}{|c|}{ Hasbrouck's Information Shares } \\
\hline & (1) & (2) & (3) & $(4)$ & (5) & (6) \\
\hline Intercept & $\begin{array}{l}0.4790^{*} \\
(7.46)\end{array}$ & $\begin{array}{c}0.4706^{*} \\
(2.25)\end{array}$ & $\begin{array}{c}0.545^{*} \\
(10.70)\end{array}$ & $\begin{array}{l}0.392 \text { * } \\
(7.47)\end{array}$ & $\begin{array}{c}0.471^{*} \\
(12.36)\end{array}$ & $\begin{array}{l}0.656^{*} \\
(26.09)\end{array}$ \\
\hline $\mathrm{MS}_{\text {Floor }}$ & $\begin{array}{l}0.342^{*} \\
(3.25)\end{array}$ & $\begin{array}{l}0.288^{*} \\
(2.25)\end{array}$ & ----- & $\begin{array}{l}0.435^{\star} \\
(4.53)\end{array}$ & ----- & ----- \\
\hline RNTR & ---- & $\begin{array}{l}0.0303 \\
(0.755)\end{array}$ & $\begin{array}{l}0.094 \text { * } \\
(2.78)\end{array}$ & ----- & $\begin{array}{l}0.133 \text { * } \\
(4.52)\end{array}$ & ----- \\
\hline $\mathrm{BAS}_{\mathrm{Floor}}-\mathrm{BaS}_{\mathrm{GLOBEX}}$ & $\begin{array}{c}-0.0145^{\star} \\
(-2.60)\end{array}$ & $\begin{array}{l}-0.013^{*} \\
(-2.14)\end{array}$ & $\begin{array}{r}-0.013^{*} \\
(-2.14)\end{array}$ & ----- & ----- & $\begin{array}{l}-0.020^{*} \\
(-4.05)\end{array}$ \\
\hline Volatility & $\begin{array}{r}-1.1663 \\
(-0.35)\end{array}$ & $\begin{array}{r}-0.9813 \\
(-0.29)\end{array}$ & $\begin{array}{l}-0.658 \\
(-0.19)\end{array}$ & $\begin{array}{l}-2.845 \\
(-0.85)\end{array}$ & $\begin{array}{l}-1.748 \\
(-0.51)\end{array}$ & $\begin{array}{c}-1.107 \\
(-0.31)\end{array}$ \\
\hline Adjusted $\mathrm{R}^{2}$ & 0.121 & 0.112 & 0.102 & 0.083 & 0.079 & 0.071 \\
\hline F statistic & $\begin{array}{l}10.039 \\
(0.000)\end{array}$ & $\begin{array}{c}7.595 \\
(0.000)\end{array}$ & $\begin{array}{c}8.411 \\
(0.000)\end{array}$ & $\begin{array}{l}10.969 \\
(0.000)\end{array}$ & $\begin{array}{c}9.99 \\
(0.000)\end{array}$ & $\begin{array}{c}8.93 \\
(0.000)\end{array}$ \\
\hline
\end{tabular}

Notes:

1. The dependent variable is midpoint Hasbrouck's information shares of floor trading.

$\mathrm{MS}_{\mathrm{FLOOR}}$ is market share of floor trading futures. RNTR denotes relative trading frequency, which is daily averages of number of trades per 3-minute periods in floor trading relative to the daily average of number of trades per 3-minute periods in screen trading. BAS $_{F L O O R}-B_{\text {BAS }}$ GLOBEX denotes the difference between bid-ask spread of floor trading and bid-ask spread of electronic trading.

2. t-statistics values are given in parentheses. *, ${ }^{* *}$ denotes significance at $1(5) \%$ level.

3. The number in parentheses under $F$ statistic is the probability value of significance(i.e. $P$ value) 
Table 8. Regression Analysis of Factors Affecting the Contribution to Price Discovery Process in British Pound Futures Markets

\begin{tabular}{|c|c|c|c|c|c|c|}
\hline \multirow[b]{2}{*}{ Dependent Variable } & \multicolumn{6}{|c|}{ Hasbrouck's Information Shares } \\
\hline & (1) & (2) & (3) & (4) & (5) & (6) \\
\hline Intercept & $\begin{array}{c}0.513 \text { * } \\
(8.41)\end{array}$ & $\begin{array}{l}0.364^{*} \\
(4.78)\end{array}$ & $\begin{array}{l}0.355^{\star} \\
(5.46)\end{array}$ & $\begin{array}{l}0.464 \text { * } \\
(6.79)\end{array}$ & $\begin{array}{r}0.323^{*} \\
(5.57)\end{array}$ & $\begin{array}{r}0.598^{*} \\
(19.62)\end{array}$ \\
\hline $\mathrm{MS}_{\text {Floor }}$ & $\begin{array}{l}0.201 \\
(1.59)\end{array}$ & $\begin{array}{l}-0.039 \\
(-0.22)\end{array}$ & ----- & $\begin{array}{l}0.262^{* *} \\
(1.97)\end{array}$ & ----- & ----- \\
\hline RNTR & ----- & $\begin{array}{l}0.228^{*} \\
(3.59)\end{array}$ & $\begin{array}{l}0.220^{*} \\
(4.31)\end{array}$ & ----- & $\begin{array}{l}0.236 \text { * } \\
(4.75)\end{array}$ & ----- \\
\hline BAS $_{\text {Floor }}$ BaS $_{\text {GLOBEX }}$ & $\begin{array}{l}-0.007 \\
(-1.36)\end{array}$ & $\begin{array}{l}-0.005 \\
(-0.92)\end{array}$ & $\begin{array}{l}-0.004 \\
(-0.91)\end{array}$ & ----- & ----- & $\begin{array}{c}-0.010^{* *} \\
(-1.99)\end{array}$ \\
\hline Volatility & $\begin{array}{l}0.921 \\
(0.22)\end{array}$ & $\begin{array}{l}5.787 \\
(1.37)\end{array}$ & $\begin{array}{l}5.623 \\
(1.34)\end{array}$ & $\begin{array}{l}-0.325 \\
(-0.08)\end{array}$ & $\begin{array}{l}5.123 \\
(1.26)\end{array}$ & $\begin{array}{c}0.987 \\
(0.24)\end{array}$ \\
\hline D_ticksize & $\begin{array}{l}-0.030 \\
(-0.96)\end{array}$ & $\begin{array}{l}0.019 \\
(0.69)\end{array}$ & $\begin{array}{r}0.021 \\
(0.77)\end{array}$ & $\begin{array}{l}-0.038 \\
(-1.17)\end{array}$ & $\begin{array}{l}0.017 \\
(0.60)\end{array}$ & $\begin{array}{l}-0.049 \\
(-1.87)\end{array}$ \\
\hline Adjusted $\mathrm{R}^{2}$ & 0.079 & 0.118 & 0.117 & 0.071 & 0.115 & 0.068 \\
\hline F statistic & $\begin{array}{l}4.59 \\
(0.001)\end{array}$ & $\begin{array}{c}6.96 \\
(0.000)\end{array}$ & $\begin{array}{c}8.70 \\
(0.000)\end{array}$ & $\begin{array}{l}5.36 \\
(0.001)\end{array}$ & $\begin{array}{c}11.29 \\
(0.000)\end{array}$ & $\begin{array}{c}5.25 \\
(0.001)\end{array}$ \\
\hline
\end{tabular}

Notes:

1. The dependent variable is midpoint Hasbrouck's information shares of floor trading. $\mathrm{MS}_{\mathrm{FLOOR}}$ is market share of floor trading futures. RNTR denotes relative trading frequency, which is daily averages of number of trades per 3-minute periods in floor trading relative to the daily average of number of trades per 3-minute periods in screen trading. BAS ${ }_{F L O O R}-B A S_{G L O B E X}$ denotes the difference between bid-ask spread of floor trading and bid-ask spread of electronic trading.

2. t-statistics values are given in parentheses. ${ }^{*},{ }^{* *}$ denotes significance at 1 (5) \% level.

3. The number in parentheses under $F$ statistic is the probability value of significance(i.e. $P$ value) 
Table 9. Regression Analysis of Factors Affecting the Contribution to Price Discovery Process in Euro Futures Markets

\begin{tabular}{|c|c|c|c|c|c|c|}
\hline \multirow[b]{2}{*}{ Dependent Variable } & \multicolumn{6}{|c|}{ Hasbrouck's Information Shares } \\
\hline & (1) & (2) & (3) & (4) & (5) & (6) \\
\hline Intercept & $\begin{array}{l}0.5631^{*} \\
(5.99)\end{array}$ & $\begin{array}{l}0.562^{*} \\
(5.53)\end{array}$ & $\begin{array}{l}0.520 \text { * } \\
(6.77)\end{array}$ & $\begin{array}{c}0.312 \text { * } \\
(11.87)\end{array}$ & $\begin{array}{r}0.342^{*} \\
(19.28)\end{array}$ & $\begin{array}{c}0.498^{*} \\
(20.36)\end{array}$ \\
\hline $\mathrm{MS}_{\text {Floor }}$ & $\begin{array}{l}-0.128 \\
(-0.75)\end{array}$ & $\begin{array}{l}-0.138 \\
(-0.77)\end{array}$ & ---- & $\begin{array}{l}0.293^{*} \\
(3.42)\end{array}$ & ----- & ----- \\
\hline RNTR & ----- & $\begin{array}{c}0.008 \\
(0.09)\end{array}$ & $\begin{array}{l}-0.027 \\
(-0.33)\end{array}$ & ----- & $\begin{array}{c}0.149^{*} \\
(3.97)\end{array}$ & ----- \\
\hline $\mathrm{BAS}_{\mathrm{Floor}}-\mathrm{BaS}_{\mathrm{GLOBEX}}$ & $\begin{array}{l}-0.021^{*} \\
(-2.82)\end{array}$ & $\begin{array}{l}-0.021 \text { * } \\
(-2.40)\end{array}$ & $\begin{array}{c}-0.019 \text { * } \\
(-2.43)\end{array}$ & ----- & ----- & $\begin{array}{l}-0.017^{*} \\
(-4.47)\end{array}$ \\
\hline Volatility & $\begin{array}{l}-0.266 \\
(-1.26)\end{array}$ & $\begin{array}{l}-0.267 \\
(-1.25)\end{array}$ & $\begin{array}{l}-0.275 \\
(-1.32)\end{array}$ & $\begin{array}{r}-0.250 \\
(-1.37)\end{array}$ & $\begin{array}{l}-0.238 \\
(-1.21)\end{array}$ & $\begin{array}{l}-0.277 \\
(-1.38)\end{array}$ \\
\hline Adjusted $\mathrm{R}^{2}$ & 0.097 & 0.097 & 0.095 & 0.077 & 0.067 & 0.095 \\
\hline F statistic & $\begin{array}{c}8.11 \\
(0.000)\end{array}$ & $\begin{array}{l}6.042 \\
(0.000)\end{array}$ & $\begin{array}{c}7.87 \\
(0.000)\end{array}$ & $\begin{array}{c}6.31 \\
(0.002)\end{array}$ & $\begin{array}{l}6.92 \\
(0.001)\end{array}$ & $\begin{array}{c}11.81 \\
(0.000)\end{array}$ \\
\hline
\end{tabular}

Notes:

1. The dependent variable is midpoint Hasbrouck's information shares of floor trading. $M S_{F L O O R}$ is market share of floor trading futures. RNTR denotes relative trading frequency, which is daily averages of number of trades per 3-minute periods in floor trading relative to the daily average of number of trades per 3-minute periods in screen trading. $\mathrm{BAS}_{\mathrm{FLOOR}}-\mathrm{BAS}_{\mathrm{GLOBEX}}$ denotes the difference between bid-ask spread of floor trading and bid-ask spread of electronic trading.

2. t-statistics values are given in parentheses. ${ }^{*},{ }^{* *}$ denotes significance at $1(5) \%$ level.

3. The number in parentheses under $F$ statistic is the probability value of significance(i.e. $P$ value) 

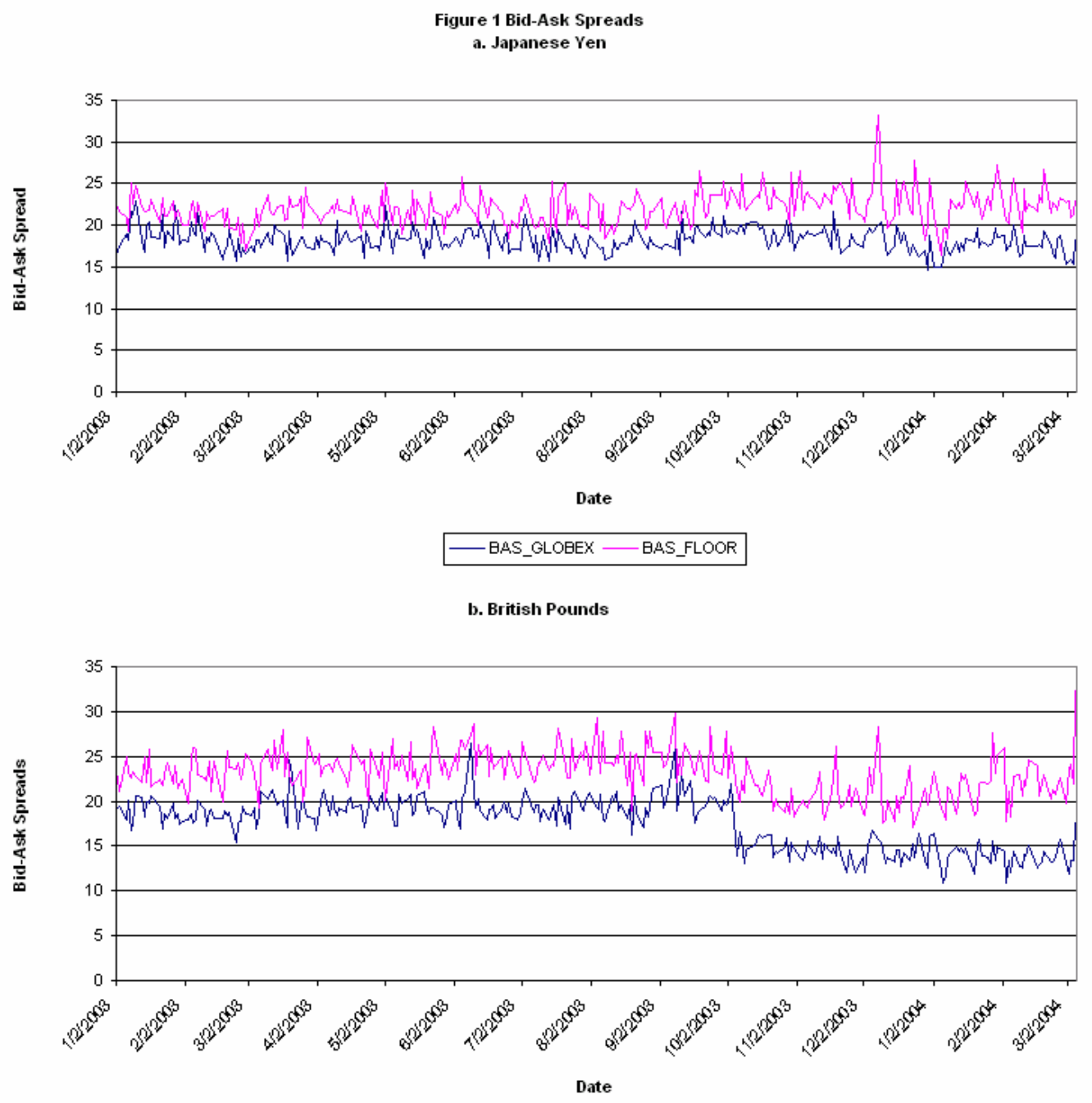

-BAS_GLOBEX — BAS_FLOOR

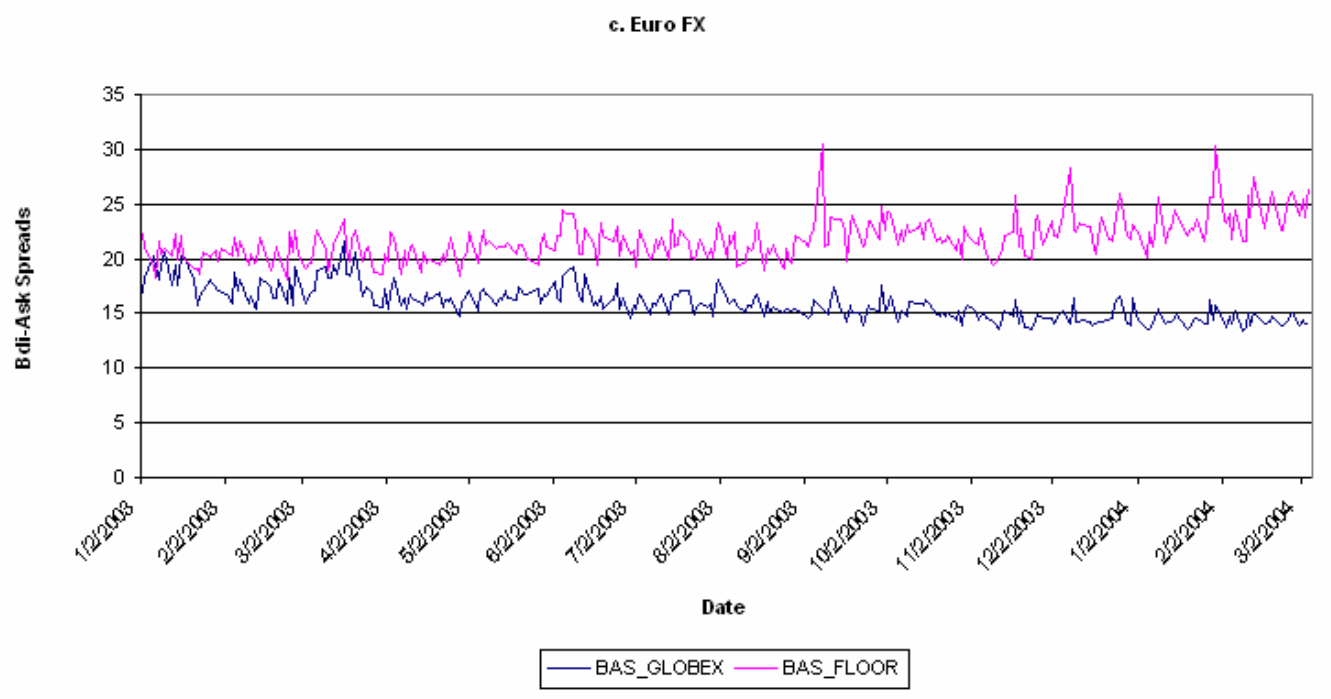



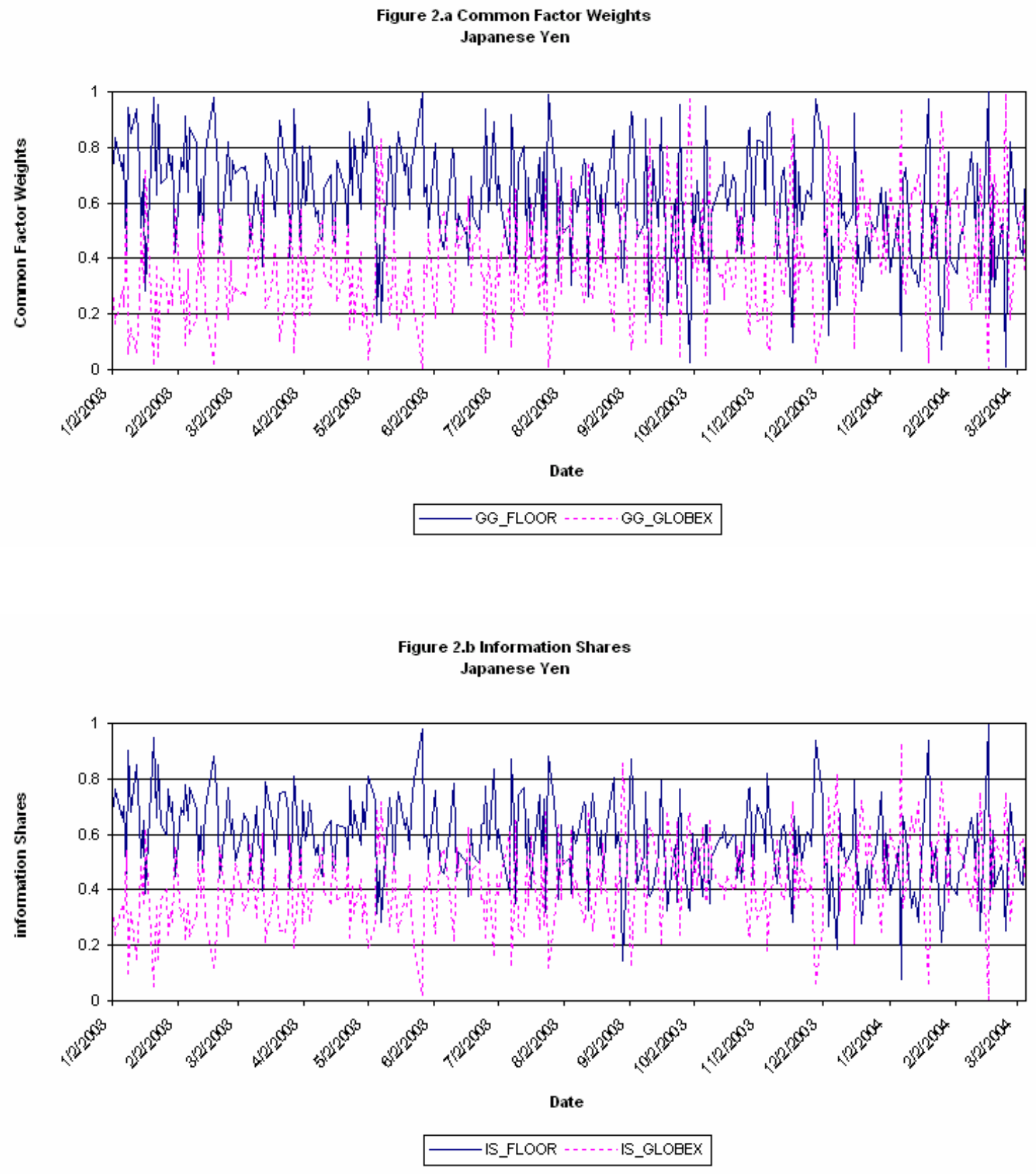
Figure 3.a Common Factor Weights British Pound
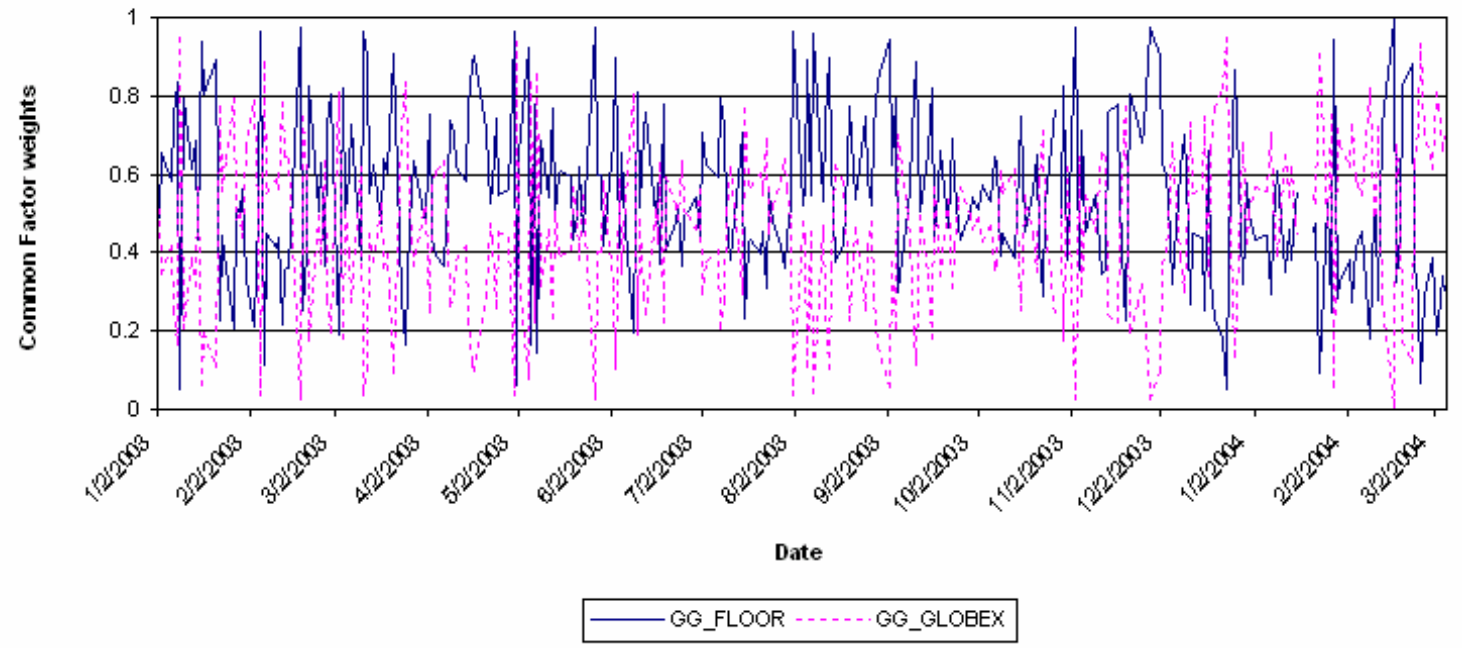

Figure 3.b Information Shares British Pound

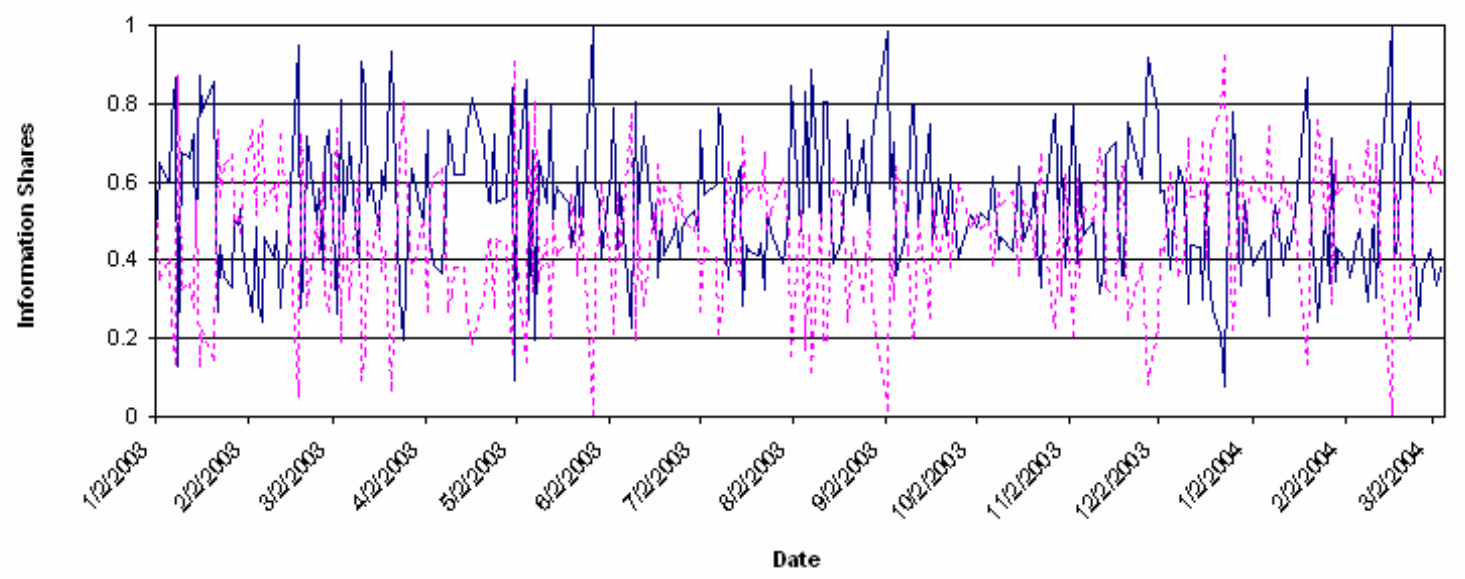

IS_FLOOR - . . . . IS_GLOBEX 
Figure 4.a Common Factor Weights Euro FX

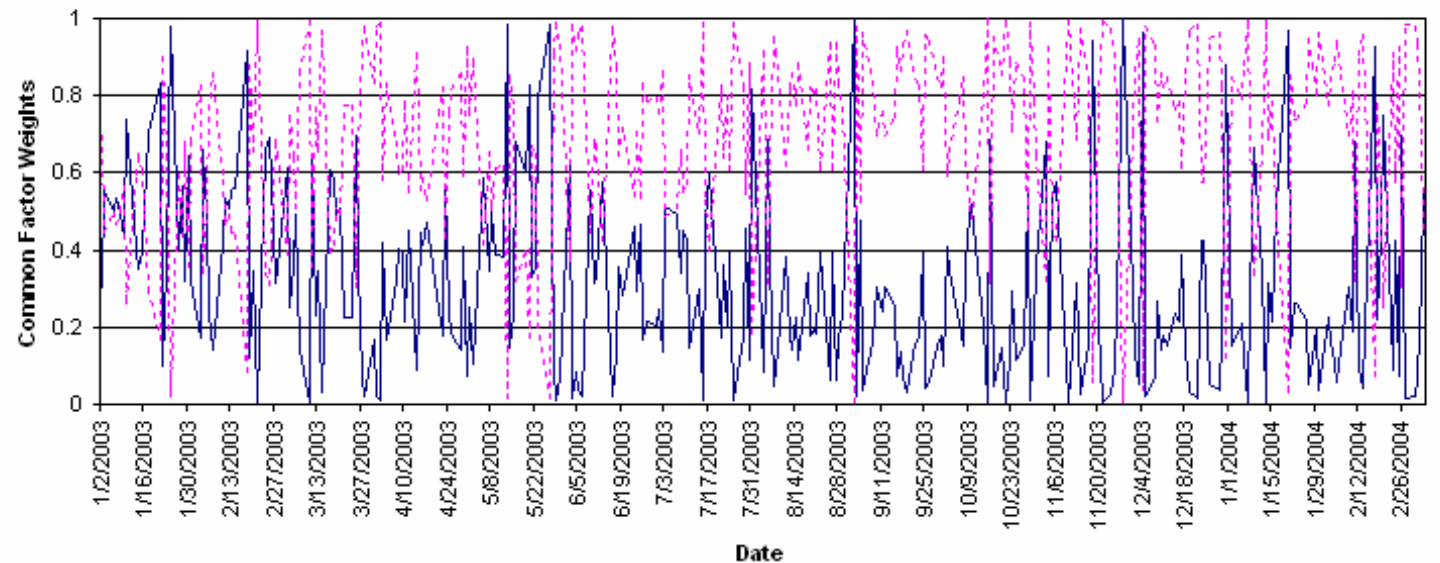

GG_FLOOR -......GG_GLOBEX

Figure 4.b Information Shares Euro FX

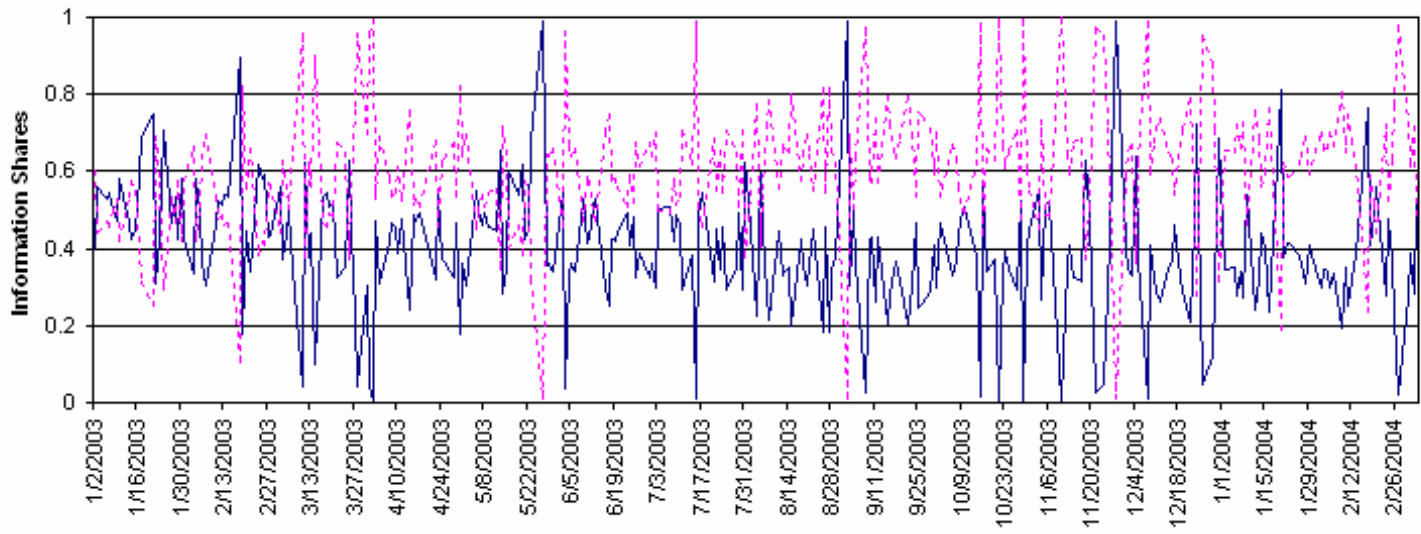

Date

IS_FLOOR - . - . - IS_GLOBEX 
Figure 5

a. Market Shares Floor vs Globex

Japanese Yen

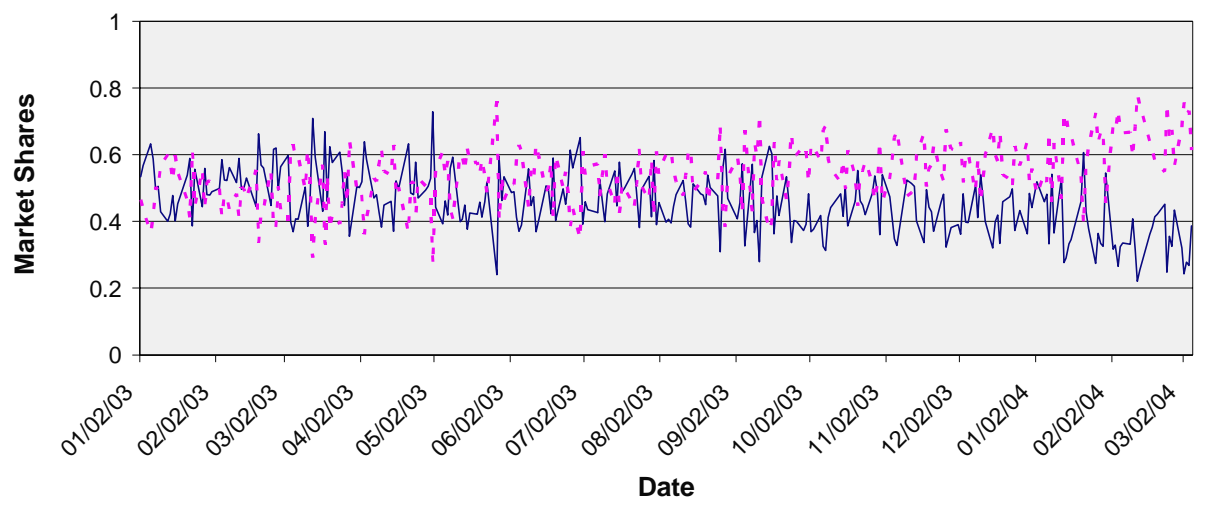

Market Share Floor - - - Market Share Globex

b. Market Shares Floor vs Globex

British Pound

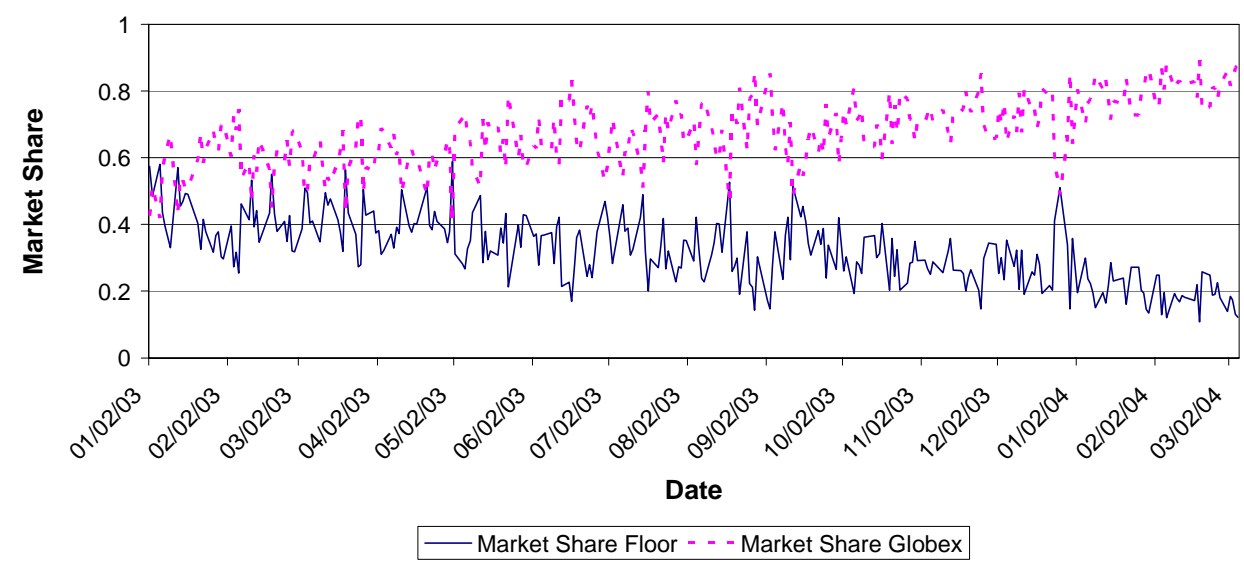

c. Market Shares Floor vs Globex Euro FX Futures

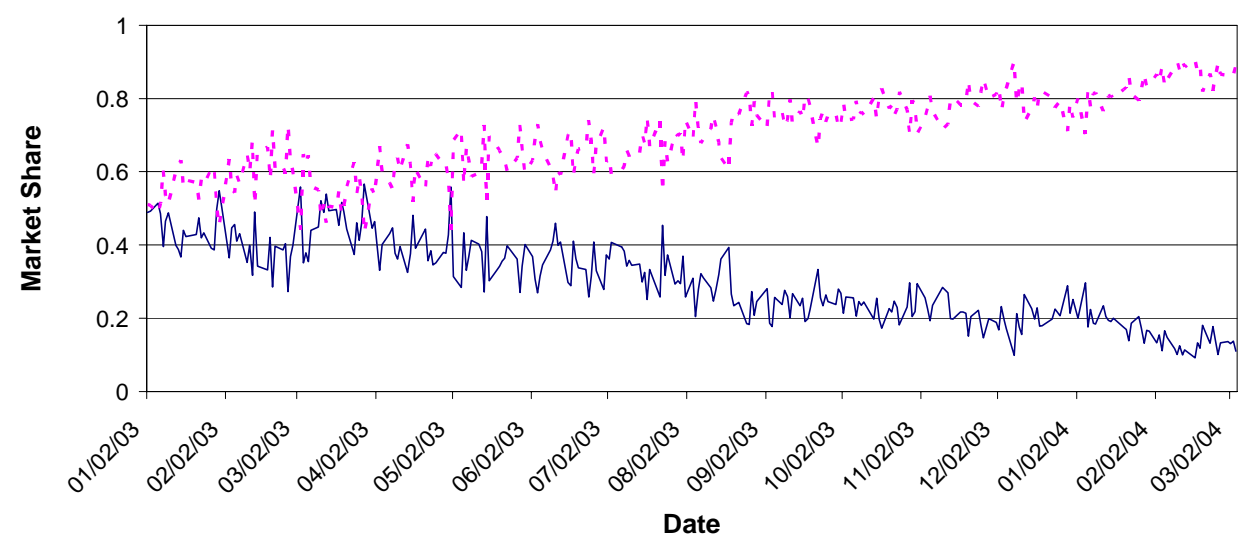

Market Share Floor - - - Market Share Globex 
Figure 6

a. Daily Averages of Number of Trades per 3-minute Japanese Yen

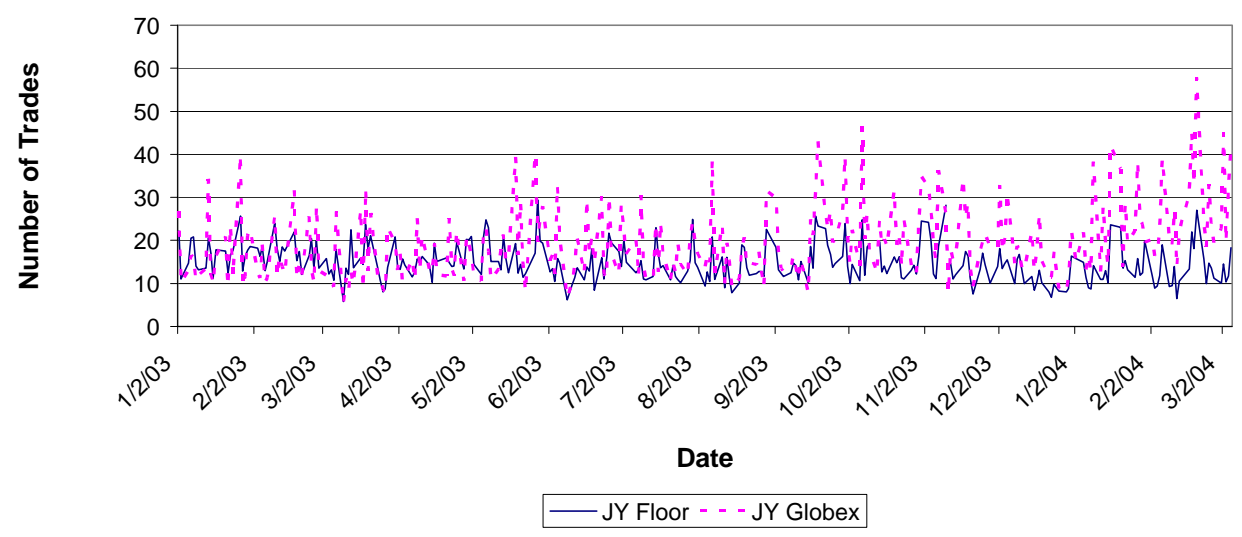

b. Daily Averages of Number of Trades per 3-Minute British Pound

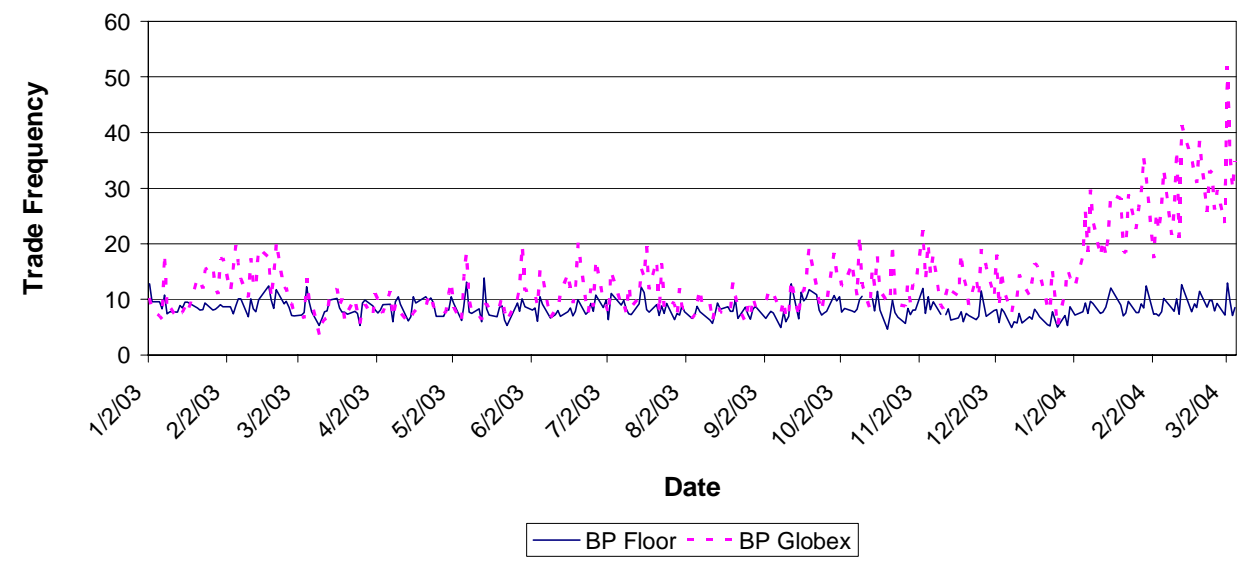

c. Daily Averages of Number of Trades per 3-Minute

Euro

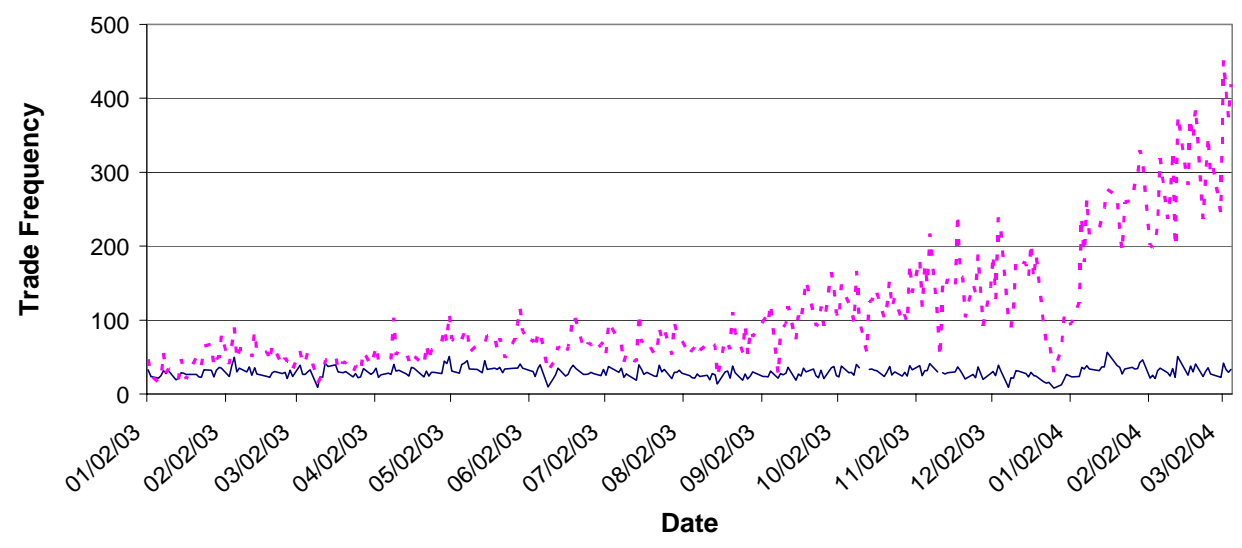

-Euro Floor - - - Euro Globex 


\section{Appendix}

Table A.1

CME Contract Specifications for Japanese Yen, British Pound, and Euro FX Futures Contracts

\begin{tabular}{|c|c|c|c|c|}
\hline Contract Size & Hours & Months & Tick Size & Price Limits \\
\hline $\begin{array}{l}\text { Japanese Yen (Open-outcry) } \\
\text { 12,500,000 Japanese Yen }\end{array}$ & $\begin{array}{l}\text { 7:20 a.m. to } 2: 00 \text { p.m. } \\
\text { Monday through Friday } \\
\text { 4:30 p.m. to } 4: 00 \text { p.m. } \\
\text { the following day; on }\end{array}$ & $\begin{array}{l}\text { March, June, } \\
\text { September, December }\end{array}$ & $\$ 12.50 /$ contract & No price limits \\
\hline Japanese Yen (GLOBEX) & Sunday trading begins at & t March, June, & & \\
\hline $12,500,000$ Japanese Yen & 5:30 p.m. & September, December & $\$ 12.50 /$ contract & No price limits \\
\hline $\begin{array}{l}\text { British Pound (Open-outcry) } \\
\text { 62,500 British Pound }\end{array}$ & $\begin{array}{l}\text { 7:20 a.m. to } 2: 00 \text { p.m. } \\
\text { Monday through Friday } \\
\text { 4:30 p.m. to } 4: 00 \text { p.m. } \\
\text { the following day; on }\end{array}$ & $\begin{array}{l}\text { March, June, } \\
\text { September, December }\end{array}$ & $\$ 6.25 /$ contract & No price limits \\
\hline $\begin{array}{l}\text { British Pound (GLOBEX) } \\
62,500 \text { British Pound }\end{array}$ & $\begin{array}{l}\text { Sunday trading begins at } \\
\text { 5:30 p.m. }\end{array}$ & $\begin{array}{l}\text { t March, June, } \\
\text { September, December }\end{array}$ & $\$ 6.25 /$ contract & No price limits \\
\hline $\begin{array}{l}\text { Euro (Open-outcry) } \\
125,000 \text { Euro }\end{array}$ & $\begin{array}{l}\text { 7:20 a.m. to } 2: 00 \text { p.m. } \\
\text { Monday through Friday } \\
\text { 4:30 p.m. to } 4: 00 \text { p.m. } \\
\text { the following day; on }\end{array}$ & $\begin{array}{l}\text { March, June, } \\
\text { September, December }\end{array}$ & $\$ 12.50 /$ contract & No price limits \\
\hline $\begin{array}{l}\text { Euro (GLOBEX) } \\
125,000 \text { Euro }\end{array}$ & $\begin{array}{l}\text { Sunday trading begins at } \\
\text { 5:30 p.m. }\end{array}$ & $\begin{array}{l}\text { t March, June, } \\
\text { September, December }\end{array}$ & $\$ 12.50 /$ contract & No price limits \\
\hline
\end{tabular}

Note: * Minimum tick size for British Pound contracts changed to \$ 6.25 effective starting with GLOBEX trading on Sunday, October 5, 2003, for the trade date of Monday, October 6, 2003. Before that minimum tick size was $\$ 12.50$. 
Table A.2 Trade Size Frequency

\begin{tabular}{lrrrrrr}
\hline \multirow{2}{*}{ Trade Size } & \multicolumn{2}{c}{ Japanese Yen } & \multicolumn{2}{c}{ British Pound } & \multicolumn{2}{c}{ Euro } \\
\cline { 5 - 6 } & \multicolumn{1}{c}{ Globex } & Floor & Globex & \multicolumn{1}{c}{ Floor } & \multicolumn{1}{c}{ Globex } \\
\hline 2 & $47.67 \%$ & $55.55 \%$ & $49.06 \%$ & $55.32 \%$ & $38.95 \%$ & $68.28 \%$ \\
3 & $18.31 \%$ & $17.32 \%$ & $17.06 \%$ & $15.15 \%$ & $20.28 \%$ & $12.66 \%$ \\
4 & $6.64 \%$ & $4.67 \%$ & $6.5 \%$ & $5.34 \%$ & $8.79 \%$ & $5.65 \%$ \\
5 & $3.43 \%$ & $2.99 \%$ & $3.96 \%$ & $3.6 \%$ & $4.5 \%$ & $2.53 \%$ \\
6 & $7.93 \%$ & $5.38 \%$ & $8.83 \%$ & $4.78 \%$ & $12.76 \%$ & $3.25 \%$ \\
7 & $1.28 \%$ & $1.17 \%$ & $1.38 \%$ & $1.29 \%$ & $1.6 \%$ & $0.68 \%$ \\
8 & $0.85 \%$ & $0.75 \%$ & $0.87 \%$ & $0.87 \%$ & $0.9 \%$ & $0.47 \%$ \\
9 & $0.79 \%$ & $0.83 \%$ & $0.87 \%$ & $1.29 \%$ & $1.08 \%$ & $0.61 \%$ \\
10 & $0.45 \%$ & $0.66 \%$ & $0.53 \%$ & $0.78 \%$ & $0.41 \%$ & $0.43 \%$ \\
$10+$ & $4.69 \%$ & $2.24 \%$ & $4.15 \%$ & $2.72 \%$ & $5.86 \%$ & $1.14 \%$ \\
\hline
\end{tabular}

